\title{
Circulating steroid hormone variations throughout different stages of prostate cancer
}

\author{
Gido Snaterse', Jenny A Visser', Wiebke Arlt² and Johannes Hofland1,2 \\ 1Section of Endocrinology, Department of Internal Medicine, Erasmus MC, Rotterdam, The Netherlands \\ 2Institute of Metabolism and Systems Research, University of Birmingham, Birmingham, UK
}

Correspondence should be addressed to J Hofland Email

j.hofland@erasmusmc.nl

\begin{abstract}
Steroid hormones play a central role in the maintenance and progression of prostate cancer. The androgen receptor is the primary driver of tumor cell proliferation and is activated by the androgens testosterone and $5 \alpha$-dihydrotestosterone. Inhibition of this pathway through medical or surgical castration improves survival in the majority of advanced prostate cancer patients. However, conversion of adrenal androgen precursors and alternative steroidogenic pathways have been found to contribute to tumor progression and resistance to treatment. The emergence of highly accurate detection methods allows us to study steroidogenic mechanisms in more detail, even after treatment with potent steroidogenic inhibitors such as the CYP17A1 inhibitor abiraterone. A clear overview of steroid hormone levels in patients throughout the local, metastatic and castration-resistant stages of prostate cancer and treatment modalities is key toward a better understanding of their role in tumor progression and treatment resistance. In this review, we summarize the currently available data on steroid hormones that have been implicated in the various stages of prostate cancer. Additionally, this review addresses the implications of these findings, highlights important studies in this field and identifies current gaps in literature.
\end{abstract}

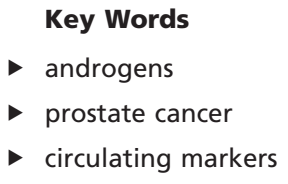

Endocrine-Related Cancer (2017) 24, R403-R420

\section{Introduction}

Prostate cancer (PC) is the most prevalent form of cancer, with the exception of non-melanoma skin cancers, in men in Western countries with an estimated 677.473 new cases in Europe and North America in 2014 (Forman \& Ferlay 2014). In addition, it is a major contributor to cancer-related mortality in these regions with an estimated 126.430 prostate cancer-related deaths, ranking third in men after lung and colorectal cancers (Forman \& Ferlay 2014). PC presents relatively late in life, after a median of 68 years and is often discovered during routine examinations or upon examination of urogenital discomfort. Early stage, localized PC can be treated with curative intent by prostatectomy or localized radiotherapy (Attard et al. 2016). Active surveillance may be employed in some cases if immediate treatment is not deemed necessary or beneficial, for example in patients with low risk (Klotz \& Emberton 2014, Hamdy et al. 2016). Metastatic prostate cancer is very difficult to treat due to its tendency to metastasize to the bone (Ye et al. 2007). As such, only palliative treatment options exist.

The androgen receptor (AR) is the main driver of prostate cancer proliferation and is primarily activated by the androgenic steroid hormones testosterone and $5 \alpha$-dihydrotestosterone (DHT). Androgens are derived

Published by Bioscientifica Ltd 
from cholesterol in a multi-step process (Fig. 1) that primarily involves the testes, although androgens precursors are also secreted from the zona reticularis of the adrenal cortex. In the prostate, circulating testosterone is converted by $5 \alpha$-reductase (SRD5A1 and 2) into DHT, which has higher affinity and improved retention at the AR compared to testosterone (Askew et al. 2007). Upon activation, the AR dissociates from its chaperone heat

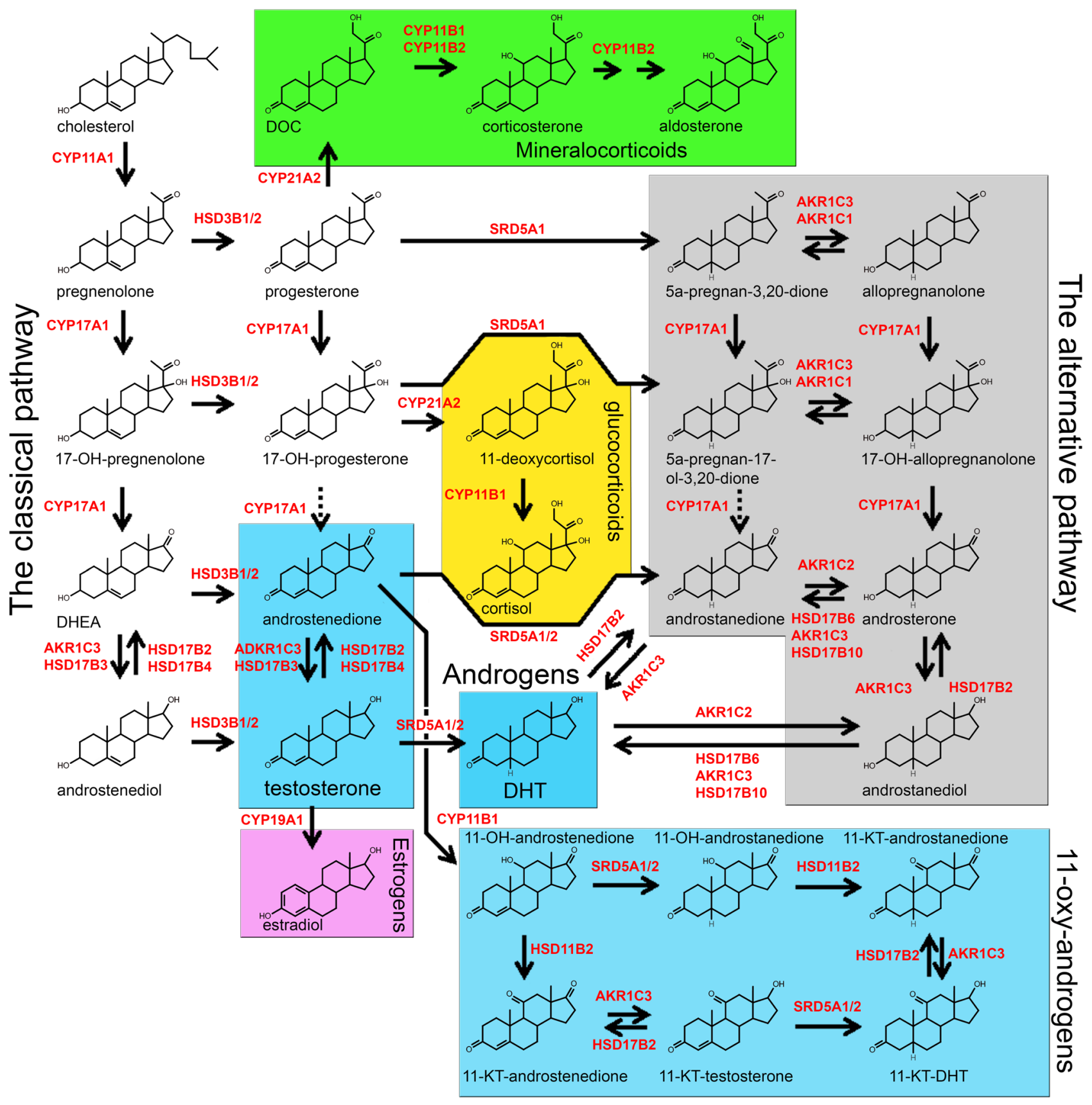

Figure 1

Overview of steroidogenesis leading to the production of androgens, estrogens, mineralocorticoids and glucocorticoids. The classical pathway produces DHT through conversion of DHEA, androstenedione and testosterone. The backdoor pathway of DHT synthesis completely bypasses canonical androgen synthesis and instead involves $5 \alpha$-reduced conversion products ultimately leading to the production of androsterone or androstanediol as precursors for DHT. An alternative pathway produces DHT with androstanedione as intermediary rather than testosterone. Black arrows depict conversions steps with the responsible enzymes listed in red. The 11-oxygenated androgen synthesis pathway is listed, starting with the conversion of androstenedione to 11-hydroxy-androstenedione. DHEA, dehydroepiandrosterone; DHEAS, dehydroepiandrosterone-sulfate; DHT, $5 \alpha$-dihydrotestosterone; DOC, deoxycorticosterone. 
shock protein 90 (HSP90) and translocates to the nucleus where it acts as a transcription factor (Trepel et al. 2010). The AR subsequently drives the expression of oncogenes causing proliferation of PC cells.

Androgen deprivation therapy (ADT) through medical castration with or without anti-androgens is the mainstay therapy for advanced prostate cancer (Perlmutter \& Lepor 2007). First-line ADT typically consists of treatment with gonadotropin-releasing hormone $(\mathrm{GnRH})$ agonists or antagonists reducing the secretion of luteinizing hormone (LH) and consequently preventing the production of testosterone in testicular Leydig cells. GnRH agonists initially cause an LH surge followed by downregulation of the GnRH receptor and sustained suppression of LH levels, while GnRH antagonists cause an immediate reduction of LH secretion. This treatment improves survival in most men, but resistance to treatment typically occurs within 2-3 years. This next stage of the disease is termed castration-resistant prostate cancer (CRPC) and is accompanied by a poor overall survival of 16-18 months on average (Harris et al. 2009).

CRPC can be treated with docetaxel chemotherapy (Tannock et al. 2004), the second-line anti-androgen axis drugs abiraterone and enzalutamide, but resistance to these drugs typically occurs within 6-18 months (Ryan et al. 2013b, Beer et al. 2014). Compared to first-line $\mathrm{ADT}$, abiraterone causes a more complete suppression of androgen synthesis by inhibiting cytochrome P450 (CYP) 17-hydroxylase/17,20-lyase (CYP17A1), a protein that catalyzes key steps in the production of androgens (Fig. 1). As a result, the production of the androgen precursors dehydroepiandrosterone (DHEA) and androstenedione and subsequently that of potent androgens is inhibited. Hence, abiraterone also suppresses adrenal androgen precursor synthesis, while first-line ADT only suppresses gonadal androgen synthesis. Abiraterone has to be co-administered with glucocorticoids as CYP17A1 inhibition results in enhanced ACTH-stimulation of the adrenal, which, in combination with the CYP17A1 block, causes significant accumulation of steroids with mineralocorticoid activity and consequently hypokalemia and hypertension (Pia et al. 2013). Interestingly, abiraterone and its metabolite $\Delta 4$-abiraterone also act as

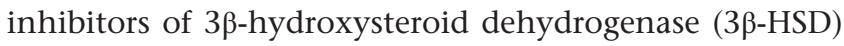
and as AR antagonists, respectively (Li et al. 2012, 2015).

Enzalutamide is a recently developed and potent antagonist of the androgen receptor. It displaces DHT at lower concentrations than earlier anti-androgens such as biculatamide (Tran et al. 2009). Compared to flutamide and biculatamide, it shows less agonistic properties in AR-mutated or AR-overexpressing settings (Tran et al. 2009, Korpal et al. 2013), which is critical as one of the mechanisms sustaining PC growth is through continuously evolving AR mutations in the cancer cells. The clinical benefits shown in phase III randomized clinical trials with enzalutamide and abiraterone suggest that $\mathrm{AR}$ activation is still an essential component of CRPC growth and progression, both before as well as after docetaxel chemotherapy (de Bono et al. 2011, Scher et al. 2012, Ryan et al. 2013b, Beer et al. 2014). Continued expression of AR-regulated genes such as prostate-specific antigen (PSA) during second-line anti-androgen axis treatment supports this hypothesis (Conteduca et al. 2016).

Several mechanisms for continued AR activation in the presence of low circulating levels of androgenic steroids have been proposed. Key observations have come from studies looking at continued relevance of the AR (Chen et al. 2004a) and residual androgen presence in PC tissues (Mohler et al. 2004). Conversion of circulating adrenal androgens androstenedione, DHEA and its sulfated form (DHEAS) into testosterone and DHT through elevation of $17 \beta$-hydroxysteroid dehydrogenase (HSD) has been shown to occur in CRPC (Stanbrough et al. 2006, Hofland et al. 2010, Kumagai et al. 2013). It has been suggested that, in the absence of testis-derived testosterone, expression of steroidogenic enzymes may allow tumor cells to generate androgens themselves (Locke et al. 2008, Montgomery et al. 2008, Ishizaki et al. 2013). However, in what way de novo synthesis of androgens contributes to the CRPC resistance phenotype in the clinical setting has not yet been determined.

Alternatively, additional DHT synthesis pathways have been proposed that completely bypass the classic androgen synthesis pathway via testosterone (Fig. 1). Other mechanisms involved in resistance to castration include AR ligand promiscuity due to mutations, allowing the AR to become activated by a variety of steroid hormones (Duff \& McEwan 2005). As such, steroid hormones other than testosterone and DHT may be of great clinical interest considering their suspected involvement in resistance mechanisms. Also, the role of steroidal ligands for activation of (hetero)dimers of various splice variants of the AR constitutes an expanding field of interest (Cao et al. 2016).

Given the crucial role of androgenic hormones during the disease evolution, the purpose of this review is to create an overview of variations in circulating steroid concentrations throughout different stages and treatment 
modalities of PC. While efforts have been undertaken to include data on all stages and modalities, most findings in literature report serum steroids levels in the treatmentnaïve stage of prostate cancer, after treatment with androgen deprivation therapy and/or abiraterone with prednisone. Thus, we will primarily discuss those stages and treatment modalities.

This overview summarizes our understanding of steroid fluxes and how they may relate to prostate cancer progression. As the AR continues to constitute a key driving factor of PC growth, detailed knowledge of all relevant ligands are of crucial importance. This could also help to identify circulating steroid levels for clinical use, i.e. for prediction of response to anti-hormonal therapy. Finally, gaps in currently available data and future prospects will be identified.

\section{Steroidogenesis}

Steroid hormones are derived from cholesterol in a sequential process involving several steroidogenic enzymes (Fig. 1). First, the cholesterol side chain is cleaved by the mitochondrial protein cytochrome $\mathrm{P} 450$ side chain cleavage enzyme CYP11A1 to generate the common steroid precursor pregnenolone (Miller \& Auchus 2011, Chien et al. 2017). This reaction occurs primarily in the gonads and adrenal cortex after stimulation with gonadotrophins and adrenocorticotrophic hormone (ACTH), respectively (Payne 1990, Sewer \& Waterman 2003). Pregnenolone can be converted by $3 \beta$-HSD type 1 or 2 (encoded by HSD3B1 and HSD3B2) to progesterone, which serves an important function in female reproduction. Progesterone in turn can by catalyzed by steroid 21-hydroxylase (CYP21A2) and 11ß-hydroxylase (CYP11B1 and CYP11B2) to generate mineralocorticoids (Ryan \& Engel 1957, Miller $\&$ Auchus 2011). Alternatively, both pregnenolone and progesterone can be hydroxylated by CYP17A1 to generate $17 \mathrm{OH}$-pregnenolone and $17 \mathrm{OH}$-progesterone, respectively (Miller \& Auchus 2011). The glucocorticoid cortisol can be synthesized from 17OH-progesterone catalyzed by CYP21A2 and CYP11B1. DHEA can be produced from 17OH-pregnenolone through the 17,20-lyase activity of CYP17A1 in conjunction with cytochrome b5 (CYB5A) (Kok et al. 2010). In the adrenal gland, DHEA is sulfated by DHEA sulfotransferase (SULT2A1) to DHEAS, and impairment of DHEA sulfation causes increased generation of active androgens (Noordam et al. 2009, Oostdijk et al. 2015). Dehydrogenization and isomerization of DHEA by $3 \beta$-HSD produces the androgen and estrogen precursor androstenedione. The production of testosterone from androstenedione is catalyzed by HSD17B3 in the testes (Lin et al. 1997, Miller \& Auchus 2011) and aldoketoreductase family 1 member C3 (AKR1C3, also known as HSD17B5) in other tissues. Increased expression of AKR1C3 has been detected in advanced CRPC (Hofland et al. 2010), and recently, it has been shown to confer resistance to androgen pathway-targeting therapies (Liu et al. 2015, 2017). A final conversion step catalyzed by the two 5-alpha reductase isozymes (SRD5A1 and SRD5A2) in the prostate generates DHT, which has the highest AR-binding affinity of all endogenous androgens (Gao et al. 2005). Alternatively, androstenedione and testosterone can be aromatized by CYP19A1 to form the estrogenic steroid hormones estrone and estradiol, respectively (Rahman et al. 2016).

In recent years, alternative DHT synthesis pathways have been proposed to contribute to intratumoral DHT while bypassing testosterone (Chang et al. 2011, Penning 2014). Especially in patients treated with the CYP17A1 inhibitor abiraterone, it is thought that accumulation of steroids upstream of CYP17A1 (Attard et al. 2008) may contribute to the production of alternative pathway steroids such as $5 \alpha$-progesterone and allopregnanolone. Thus, changes in steroid serum levels may have clinical consequences for treatment resistance that we are not fully aware of yet.

\section{Steroid hormone levels throughout the different stages of prostate cancer}

Several different units of measurements are used in literature to report serum steroid concentrations (e.g. $\mathrm{ng} / \mathrm{mL}, \mathrm{ng} / \mathrm{dL}, \mathrm{nM}$ ). To facilitate the comparison of findings from different publications and between different steroids we have chosen to summarize all data in this article in molar concentrations. An overview of conversion factors can be found in Table 1. Unless specified, steroid concentrations of controls were obtained from healthy individuals in the relevant age range that resembles those at risk or suffering from prostate cancer ( $>50$ years old), since steroid levels can vary significantly by age (Belanger et al. 1994). Data on circulating levels of the relevant steroid hormones have been summarized in Fig. 2 and Supplementary Table 1 (see section on supplementary data given at the end of this article).

The modality used to measure steroid levels also differs between studies. The recent advance of novel liquid chromatography tandem mass spectrometry (LC-MS/MS)
(C) 2017 Society for Endocrinology Printed in Great Britain
Published by Bioscientifica Ltd 
Table 1 An overview of steroid hormones that have been associated with the prostate cancer, including steroids of the classical, alternative and backdoor pathways of DHT synthesis.

\begin{tabular}{|c|c|c|c|}
\hline Steroid hormone & Alternative names & Molecular weight & Conversion factor \\
\hline 11-deoxycorticosterone & $\mathrm{DOC}$ & 330.46 & 3.03 \\
\hline 11-deoxycortisol & $\mathrm{S}$ & 346.46 & 2.89 \\
\hline 17-hydroxy-allopregnanolone & & 334.49 & 2.99 \\
\hline 17-hydroxy-pregnenolone & 17OH-Preg & 332.48 & 3.01 \\
\hline 17-hydroxy-progesterone & 170H-Prog & 330.46 & 3.03 \\
\hline $5 \alpha$-dihydrotestosterone & DHT & 290.44 & 3.44 \\
\hline $5 \alpha$-pregnan-17-ol-3,20-dione & & 332.48 & 3.01 \\
\hline $5 \alpha$-pregnane-3,20-dione & $5 \alpha$-progesterone & 316.48 & 3.16 \\
\hline Androstanediol-glucoronide & ADG & 468.59 & 2.13 \\
\hline Aldosterone & & 360.45 & 2.77 \\
\hline Allopregnanolone & & 318.49 & 3.14 \\
\hline Androstanediol & $3 \alpha$-androstanediol & 292.46 & 3.42 \\
\hline Androstanedione & $5 \alpha$-dione & 288.42 & 3.47 \\
\hline Androstenediol & & 290.44 & 3.44 \\
\hline Androstenedione & $\Delta 4$-dione, adione & 286.4 & 3.49 \\
\hline Androsterone & & 290.44 & 3.44 \\
\hline Corticosterone & B & 346.47 & 2.89 \\
\hline Cortisol & hydrocortisone & 362.46 & 2.76 \\
\hline Dehydroepiandrosterone & DHEA & 288.42 & 3.47 \\
\hline Dehydroepiandrosterone-sulfate & DHEAS & 368.49 & 2.71 \\
\hline 17b-estradiol & $\mathrm{E}_{2}$ & 272.39 & 3.67 \\
\hline Pregnenolone & & 316.48 & 3.16 \\
\hline Progesterone & & 314.46 & 3.18 \\
\hline Testosterone & $\mathrm{T}$ & 288.42 & 3.47 \\
\hline
\end{tabular}

techniques in the last decade has significantly improved the field of steroid hormone estimations. Compared to radioimmunoassays (RIA) and chemiluminescence immunoassays, LC-MS/MS can reach a lower limit of quantification, lacks cross-reactivity and can perform multi-steroid measurements in a single run. This review includes results from both mass spectrometryand antibody-based assays to give a broad overview of the available data, although LC-MS/MS data are generally preferred.

\section{Testosterone}

Targeting testosterone synthesis has been central to prostate cancer treatment ever since the discovery of the effects of castration on prostate cancer by Huggins, more than 70 years ago, was awarded with the Nobel Prize. As such, many studies have evaluated testosterone levels in order to determine treatment efficacy, predict cancer or progression risk or to study molecular pathways related to AR signaling. Importantly, testosterone shows a diurnal rhythm with peak levels in the morning and nadir at night, although the circadian amplitude dissipates with increasing age (Bremner et al. 1983, Diver et al. 2003).

Serum testosterone concentrations in healthy controls are reported with high consistency throughout multiple larger studies, which included $>1000$ subjects (Belanger et al. 1994, Severi et al. 2006, Crawford et al. 2007, Daniels et al. 2010, Mondul et al. 2010, Tsilidis et al. 2015, Schenk et al. 2016) as well as in a large meta-analysis of 18 studies by the Endogenous Hormones and Prostate Cancer Collaborative group (EHPCCG) (Endogenous Hormones and Prostate Cancer Collaborative Group 2008). These data are in line with data obtained from LC-MS/MS measurements in another study (Yamashita et al. 2009). The reported median testosterone concentrations in these studies lie between 10 and $24 \mathrm{nM}$ and interquartile range (IQR) values varied from 8.7 to $29.9 \mathrm{nM}$ for the control populations (Endogenous Hormones and Prostate Cancer Collaborative Group 2008). Several smaller studies reported serum testosterone mean values that fall securely within this 'normal' range (Gann et al. 1996, Chen et al. 2003, Trifiro et al. 2010).

Relevant confounders of serum testosterone levels are age, body mass index (BMI) and chronic illness (Wu et al. 2008). Total serum testosterone declines by approximately $1 \mathrm{nM}$ per decade (Harman et al. 2001). Taking the concomitant rise of sex hormone-binding globulin (SHBG) into account, the decline in circulating levels of unbound or free testosterone is even more pronounced with age. Through multifactorial causes obesity is also associated with lower levels of total testosterone. However, free 
Pregnenolone

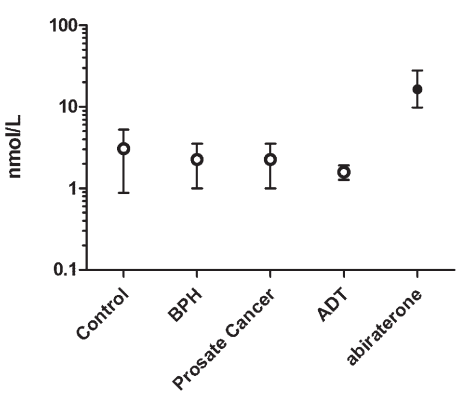

DHEA

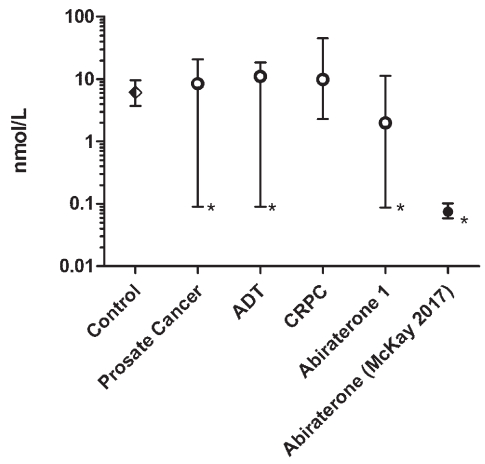

Testosterone

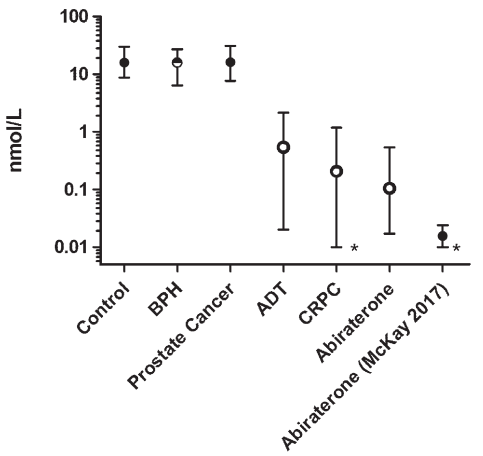

Progesterone

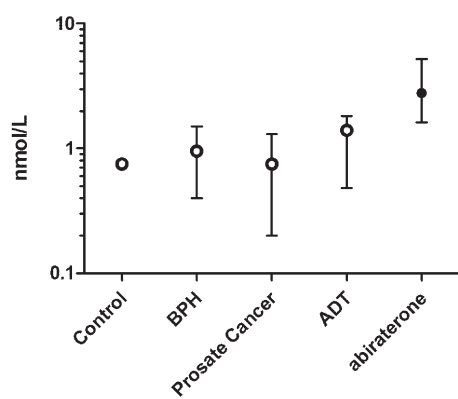

DHEAS

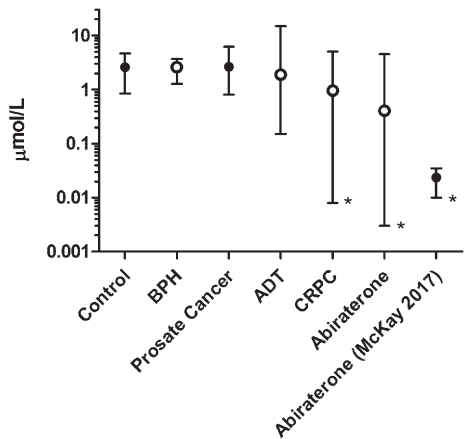

DHT

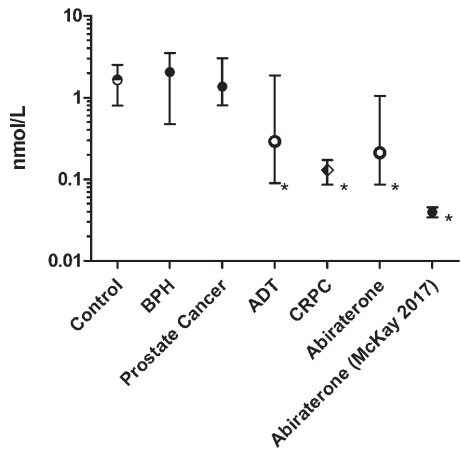

17-hydroxy-pregnenolone

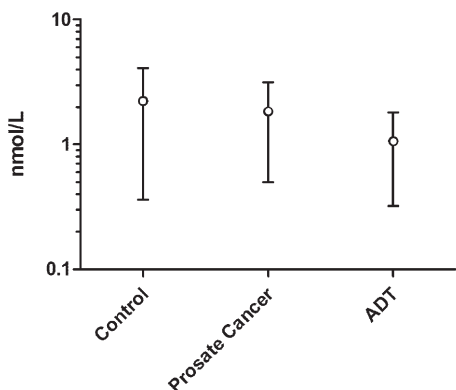

Androstenedione
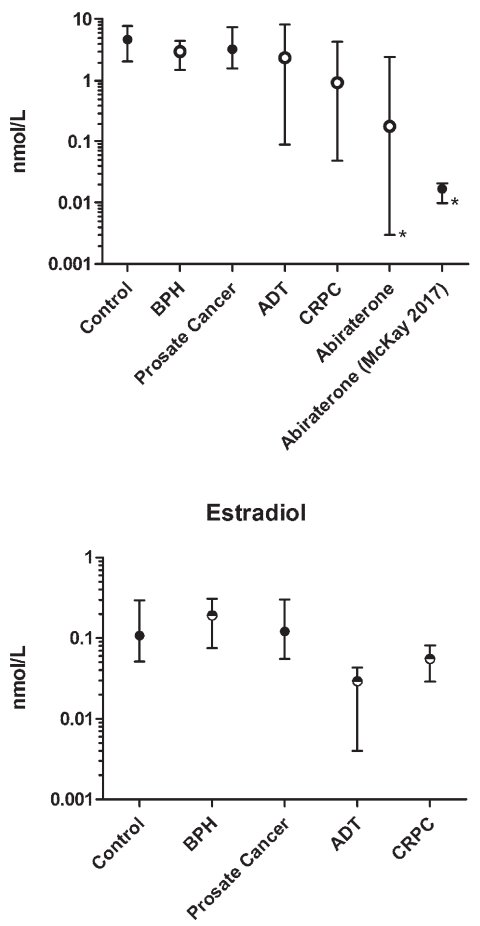

Figure 2

Serum steroid concentrations in healthy men and patients with prostate cancer during different modalities of treatment. The symbols depict the median of reported values from literature. A complete overview of papers reporting serum values for these steroids is available in Supplementary Table 1. Interquartile range data are presented when a full circle symbol is used. A semi-full circle depicts $95 \%$ confidence interval data. An open circle depicts range data. A semi-full diamond depicts a range of mean values from literature. Values from the recent McKay et al. (2017) study are listed independently because they achieved lower limits of quantification than other studies. *levels at or below the lower limit of quantification in the original study. The $y$-axis steroid values are spaced logarithmically. ADT, androgen deprivation therapy; BPH, benign prostatic hyperplasia; CRPC, castration-resistant prostate cancer; DHEA, dehydroepiandrosterone; DHEAS, dehydroepiandrosterone-sulfate; DHT, $5 \alpha$-dihydrotestosterone.

testosterone concentrations remain normal in moderately obese subjects $(\mathrm{BMI}<35)$ due to the concurrent decline in SHBG (Giagulli et al. 1994, Saboor Aftab et al. 2013). Importantly, the elderly male population displays a high prevalence of chronic diseases. The presence of comorbidity is also accompanied by lower testosterone levels (Ahern et al. 2016).
Several studies comparing healthy to benign prostatic hyperplasia (BPH) subjects have reported equal testosterone levels, with mean values varying around $15 \mathrm{nM}$ (Hammond et al. 1978, Heracek et al. 2007a, Grosman et al. 2010). Similarly, multiple studies report serum testosterone levels in subjects with localized PC that are on par with healthy controls (Gann et al. 1996, 
Endogenous Hormones and Prostate Cancer Collaborative Group 2008, Schenk et al. 2016). Serum testosterone values did not appear to predict the incidence of prostate cancer (Daniels et al. 2010, Schenk et al. 2016). In contrast, no large differences were observed between aggressive (Gleason $\geq 7$ ) and indolent tumors (Gleason $<7$ ) (Severi et al. 2006, Muller et al. 2012).

After orchiectomy or ADT, intended to lower serum testosterone below 'castrate levels', serum testosterone levels change dramatically. The established cut-off for castrate serum testosterone levels is currently $1.73 \mathrm{nM}$ $(50 \mathrm{ng} / \mathrm{dL})$. However, many studies report mean levels far below this limit using both immunoassays and LC-MS/MS, usually $\leq 0.5 \mathrm{nM}$ (Rohl \& Beuke 1992, Ishizaki et al. 2012, Hara et al. 2012, 2013, Mostaghel et al. 2014). This is slightly lower than the $\mathrm{EC}_{50}$ for AR activation of $0.63 \mathrm{nM}$ reported in literature (Sonneveld et al. 2005) and near the significant effect threshold $(0.3 \mathrm{nM})$ observed in another study (Campana et al. 2016). Testosterone levels of orchiectomized and ADT-treated subjects were comparable, although a statistically significant difference was observed in a study employing sensitive isotope dilution LC-MS/MS in 66 subjects (orchiectomy: $0.319 \mathrm{nM}$; ADT: $0.138 \mathrm{nM}$ ) (van der Sluis et al. 2012). Another study compared serum testosterone levels in ADT-responsive, ADT-nonresponsive and CRPC patients after treatment with combined androgen block but did not observe significant differences with mean levels of $0.52,0.38$ and $0.31 \mathrm{nM}$, respectively. Despite the clear effect of ADT on serum testosterone levels, intratumoral testosterone levels in CRPC tissues are similar $(2.78 \mathrm{nM}$ vs $3.26 \mathrm{nM}$, respectively) (Mohler et al. 2004, Titus et al. 2005) or even higher (Montgomery et al. 2008) compared to pre-castrate levels. Intratumoral testosterone levels are moderately reduced shortly after the initiation of LHRH antagonist treatment, as measured by LC-MS/MS (Shaw et al. 2016), suggesting intratumoral compensatory mechanisms during long-term ADT.

Finally, serum testosterone levels can be decreased to a greater extent, in a range that can only be measured reliably with LC-MS/MS, by abiraterone treatment. In one trial, median serum testosterone in CRPC patients declined from $0.35 \mathrm{nM}$ at baseline to $0.02 \mathrm{nM}$ after 12 weeks treatment with $1000 \mathrm{mg}$ abiraterone and $5 \mathrm{mg}$ prednisone daily (McKay et al. 2017). This is lower than the in vitro activation thresholds observed in literature, although intracellular levels may differ (Sonneveld et al. 2005, Campana et al. 2016). Equally low serum testosterone levels were detected in two other studies (Attard et al. 2008,
Ryan et al. 2014) while a milder reduction was observed in a study that compared ketoconazole-progressive patients with abiraterone treatment (Kim et al. 2014).

A single study reported on post-enzalutamide levels in the neo-adjuvant setting. After 180 days of enzalutamideonly treatment, serum and intratumoral testosterone levels were significantly increased when compared to both baseline and combination treatment consisting of enzalutamide, dutasteride and androgen deprivation therapy (Montgomery et al. 2017). This is likely due to augmented hypothalamic-pituitary-gonadal axis activity following ablation of negative feedback by enzalutamide. The additive effects of enzalutamide on local or circulating androgen levels including testosterone in the castrate setting are unknown.

\section{5 $\alpha$-dihydrotestosterone (DHT)}

As the most potent natural androgen, DHT constitutes an essential target for the treatment of prostate cancer. DHT is synthesized within prostate cells from testosterone by the $5 \alpha$-reductases, but is also present in serum. In control subjects, mean and median values between 1.2 and $2.0 \mathrm{nM}$ have been reported by several studies, including one study employing LC-MS/MS (Hammond et al. 1978, Gann et al. 1996, Yamashita et al. 2009, Trifiro et al. 2010, Stanczyk et al. 2013). Similar values were observed in control subjects in the meta-study of the EHPCCG (Endogenous Hormones and Prostate Cancer Collaborative Group 2008), with interquartile ranges varying between 0.91 and $2.52 \mathrm{nM}$ across 7 reviewed studies. A slightly higher mean serum DHT concentration of $3.22 \mathrm{nM}$ was observed by Belanger and coworkers, which could reflect the occurrence of cross-reactivity in their radioimmunoassay (Belanger et al. 1994, Yarrow et al. 2013, Krasowski et al. 2014).

In BPH subjects, reported values were quite similar (Hammond et al. 1978, Heracek et al. 2007a) although a small but statistically significant difference was detected in a follow-up study comparing men who did not develop BPH $(1.44 \mathrm{nM})$ compared to men who did $(1.65 \mathrm{nM})$ (Parsons et al. 2010). DHT levels can be strongly reduced with the $5 \alpha$-reductase inhibitors finasteride and dutasteride. This has been tested in BPH patients, resulting in serum DHT levels below $0.03 \mathrm{nM}$, measured by mass spectrometry, after 24 weeks of treatment with $2.5-5 \mathrm{mg}$ of dutasteride per day (Clark et al. 2004).

Determined by both RIA and LC-MS/MS, mean serum DHT levels in PC patients before castration are similar 
to healthy controls (Hammond et al. 1978, Endogenous Hormones and Prostate Cancer Collaborative Group 2008, Miyoshi et al. 2014) but can be reduced to $0.1-0.5 \mathrm{nM}$ (mean) by either orchiectomy (Rohl \& Beuke 1992) or ADT (Hara et al. 2013, Mostaghel et al. 2014, Taplin et al. 2014). Even lower levels $(<0.086 \mathrm{nM}$ and $<0.44 \mathrm{nM})$ were achieved in two studies using LC-MS/MS (Kim et al. 2014, McKay et al. 2017) in which CRPC patients were treated with abiraterone and prednisone. DHT concentrations necessary to activate the AR in vitro are estimated to be between 0.05 and $0.5 \mathrm{nM}$, and in some mammaliancell-based luciferase assays $\mathrm{EC}_{50}$ values as low as $0.01 \mathrm{nM}$ were measured (Sonneveld et al. 2005, Dennis et al. 2008, Campana et al. 2016, Lallous et al. 2016). As such, values detected in castrated patients appear to approximate the $\mathrm{EC}_{50}$ values. DHT values in some abiraterone-treated patients were lower than $0.086 \mathrm{nM}$ in one study but could not be assessed more accurately because they reached the lower limits of quantification (Kim et al. 2014). Therefore, it remains unclear whether abiraterone lowers serum DHT concentration below the AR activation limits. In contrast to abiraterone, enzalutamide in the neoadjuvant setting increased circulating DHT levels compared to baseline (Montgomery et al. 2017).

\section{Androstenedione}

Serum concentrations of the androgen precursor androstenedione are generally lower than testosterone levels in men, with several studies reporting mean values between 2.95 and $4.7 \mathrm{nM}$ (Belanger et al. 1994, Severi et al. 2006, Stanczyk et al. 2013, Tsilidis et al. 2015). This is in line with the findings of the EHPCCG, who report IQR values between 2.07 and $7.80 \mathrm{nM}$ (Endogenous Hormones and Prostate Cancer Collaborative Group 2008).

Circulating androstenedione levels appear to be relatively similar in both BPH (Hammond et al. 1978) and PC subjects (Hammond et al. 1978, Chen et al. 2003, Severi et al. 2006, Endogenous Hormones and Prostate Cancer Collaborative Group 2008). Unlike testosterone and DHT, serum androstenedione levels are not dramatically affected by either orchiectomy or ADT (Ayub \& Levell 1990, van der Sluis et al. 2012, Mostaghel et al. 2014). One study detected a mild albeit statistically significant decrease in androstenedione levels (5.58-2.89 nM after ADT), although still within the ranges reported by other studies (Hara et al. 2013). This is in agreement with the adrenal cortex being the predominant source of androstenedione in men and with the adrenal cortex contributing to ongoing AR activation within PC cells after castration. Similar to testosterone and DHT, neoadjuvant enzalutamide treatment also increased serum androstenedione levels (Montgomery et al. 2017).

In contrast, abiraterone dramatically lowers serum androstenedione levels in CRPC patients, since CYP17A1 catalyzes key steps in the synthesis of androstenedione. Mean values between 0.011 and $0.27 \mathrm{nM}$ have been reported using LC-MS/MS in CRPC patients after 12-24 weeks of abiraterone and prednisone treatment (Attard et al. 2012, Mostaghel et al. 2014, Taplin et al. 2014). Circulating androstenedione levels in untreated men are around or below the $\mathrm{EC}_{50}$ values for AR activation observed in vitro, which vary from $5.01 \mathrm{nM}$ to $70 \mathrm{nM}$ (Chen et al. 2004b, Sonneveld et al. 2005). As such, it is unlikely that androstenedione in itself is a major contributor to AR activation in prostate cancer, especially after suppression by abiraterone.

\section{DHEA}

DHEA is an important precursor of androstenedione and testosterone, although much of it circulates in the form of its inactive sulfate ester, DHEAS. Serum DHEA levels decline strongly with age and mean concentrations are 4.03-9.07 nM in subjects aged 50-80 years (Belanger et al. 1994), a process commonly referred to as adrenopause, which is slightly inaccurate as glucocorticoids and mineralocorticoids do not decline with age. In vitro data suggest that the required DHEA concentration to activate the AR is above $100 \mathrm{nM}$ (Mizokami et al. 2004), meaning that DHEA is unlikely to contribute to AR activation at any stage in vivo. DHEA levels appear normal in subjects with localized PC (Nishiyama et al. 2007, Taplin et al. 2014), although this is difficult to judge because of small sample sizes and the large differences between studies, as well as the high intra-individual variability of serum levels, despite the use of LC-MS/MS (Taplin et al. 2014; range: $0.08-20.57 \mathrm{nM}$ ). DHEA levels were also not significantly affected by ADT or ADT in combination with other anti-hormonal agents (Mostaghel et al. 2014). Again, treatment with enzalutamide in the neoadjuvant setting significantly stimulated serum DHEA levels (Montgomery et al. 2017).

Like androstenedione, serum DHEA levels are reduced upon treatment with abiraterone with reported values between 0.08 and $2.7 \mathrm{nM}$ in several LC-MS/MS studies (Attard et al. 2008, Taplin et al. 2014, McKay et al. 2017). A possible explanation for circulating DHEA levels not

Published by Bioscientifica Ltd. 
being reduced as strongly as testosterone may be the continued presence of high (albeit diminished) levels of DHEAS after abiraterone treatment.

\section{DHEAS}

Serum DHEAS levels are higher than those of all other androgenic steroids combined and it is the only one that circulates in the micromolar range. DHEAS is a not an AR agonist (Bjerregaard-Olesen et al. 2016), but it can be converted into more potent androgens after removal of the sulfate group by the enzyme steroid sulfatase (STS) and conversion by $3 \beta-H S D$ and $17 \beta-H S D$. STS activity has no relevant impact on circulating DHEAS levels (Hammer et al. 2005) but desulfation of DHEAS can occur in prostate cells (Purohit \& Foster 2012). In control subjects, serum DHEAS mean and median values typically fall between 1.2 and 3.2 $\mu \mathrm{M}$ (Belanger et al. 1994, Severi et al. 2006, Endogenous Hormones and Prostate Cancer Collaborative Group 2008), with reported IQRs between 0.8 and $4.68 \mu \mathrm{M}$ by the EHPCCG.

Slightly lower DHEAS values were observed in $\mathrm{BPH}(2.6 \mu \mathrm{M})$ and PC subjects $(1.9 \mu \mathrm{M})$ compared to control subjects $(4.3 \mu \mathrm{M})$ in one study, but sample size was limited (Mitamura et al. 2003). Additionally, lower DHEAS levels were associated with an increased risk for aggressive PC (Severi et al. 2006). The EHPCCG metastudy did not detect the differences between control and PC subjects (Endogenous Hormones and Prostate Cancer Collaborative Group 2008).

Serum DHEAS levels appeared unaffected by orchiectomy and ADT in two LC-MS/MS studies (van der Sluis et al. 2012, Taplin et al. 2014), although Hara and coworkers observed a statistically significant $38 \%$ decrease in patients with localized PC after 6 months of ADT (Hara et al. 2013). Reported DHEAS levels in CRPC subjects were lower in some studies, with mean values before abiraterone treatment around $0.55-1.0 \mu \mathrm{M}$ (Attard et al. 2008, Ryan et al. 2014), although values in CRPC patients can vary wildly (Matsubara et al. 2014). In contrast to the studies of Attard and coworkers and Ryan and coworkers much higher pretreatment mean values $(5.2-6.2 \mu \mathrm{M})$ were reported in another study employing LC-MS/MS (Taplin et al. 2014, Attard et al. 2008, Ryan et al. 2014). This may be due to population differences between these studies. The latter study included younger patients (median 55 years) with localized disease, good performance status and no prior prostate cancer targeting treatment while the former studies included older (median for both studies:
69 years) patients previously treated with - and progressed on - ADT and/or chemotherapy and were in some cases prescribed corticosteroids. In each of these studies, however, abiraterone treatment strongly reduced DHEAS levels by $80-90 \%$, with on-treatment values between 0.14 and $0.4 \mu \mathrm{M}$. Even lower post-abiraterone treatment levels (median $<0.03 \mu \mathrm{M}$ ) have been reported using highly sensitive LC-ESI-MS/MS by McKay and coworkers after 24 weeks of treatment (McKay et al. 2017). Importantly, not only abiraterone but also administration of prednisone contributes to this effect through attenuation of ACTH levels. As markers of adrenocortical function, pretreatment levels of DHEA, DHEAS and androstenedione are all predictive biomarkers for abiraterone efficacy in CRPC patients (Attard et al. 2009). Serum testosterone, androstenedione and DHEAS also proved to be prognostic for overall survival in a cohort treated with abiraterone (Ryan et al. 2013a).

\section{Estradiol}

Although initially employed solely as treatment to reduce serum testosterone levels, interest in the role of endogenous estradiol $\left(\mathrm{E}_{2}\right)$ has risen in recent years, especially as a possible factor in the development of prostate cancer. A shift from apoptosis-inducing estrogen receptor (ER)- $\beta$ signaling to the growth-stimulatory effects of ER- $\alpha$ during PC evolution suggests a proliferative role of estrogens in advanced disease stages (Rahman et al. 2016). $\mathrm{E}_{2}$ levels are very low in male subjects, with reported mean concentrations for healthy control groups in the 82-234 pM range (Hammond et al. 1978, Hsing \& Comstock 1993, Belanger et al. 1994, Chen et al. 2003, Severi et al. 2006, Endogenous Hormones and Prostate Cancer Collaborative Group 2008, Grosman et al. 2010). Findings in the meta-study of the EHPCCG show that there is a high level of disparity between different studies, with IQR values ranging from $51-84 \mathrm{pM}$ to 173-296 pM. No differences in serum $\mathrm{E}_{2}$ levels were detected between control and BPH subjects (Hammond et al. 1978, Grosman et al. 2010).

Most studies comparing $\mathrm{E}_{2}$ concentrations in control and PC subjects did not find differences between these groups (Hsing \& Comstock 1993, Severi et al. 2006, Endogenous Hormones and Prostate Cancer Collaborative Group 2008, Daniels et al. 2010), although a single study reported higher levels in the PC group (200.1 pM) compared to controls (156.4 pM) (Grosman et al. 2010). Testosterone is converted into $\mathrm{E}_{2}$ by aromatase and, 
consequently, targeting testosterone synthesis with ADT will also reduce serum $\mathrm{E}_{2}$ levels. Several studies observed this effect, where ADT was able to reduce mean serum $\mathrm{E}_{2}$ to levels in the range of 4-33 pM (Kitahara et al. 1999, Basaria et al. 2002, Qin et al. 2013). Qin and coworkers noted a small non-significant increase in $\mathrm{E}_{2}$ levels in PC patients who progressed on complete androgen block (CAB) therapy, which combines regular ADT with antiandrogens and in some cases $5 \alpha$-reductase inhibitors (Qin et al. 2013). Only one study reported serum $\mathrm{E}_{2}$ levels in abiraterone-treated CRPC patients. After 4 weeks of treatment, the median $\mathrm{E}_{2}$ level was further reduced from $7.2 \mathrm{pM}$ to $2.9 \mathrm{pM}$ (Attard et al. 2008). Patients with higher pretreatment $\mathrm{E}_{2}$ levels were also more likely to experience a $\geq 50 \%$ PSA decline following abiraterone treatment (Attard et al. 2009).

\section{Pregnenolone and progesterone}

Pregnenolone is the common steroid hormone precursor and is synthesized from cholesterol by CYP11A1. Pregnenolone is not an attractive target for the treatment of prostate cancer because of potential side effects caused by glucocorticoid and mineralocorticoid deficiencies. Serum pregnenolone levels have not been investigated in great detail. The reported values in subjects with $\mathrm{BPH}$ or PC appear to be similar to those in healthy controls (1.5-2.5 nM) (Hammond et al. 1977, 1978, Belanger et al. 1994). Elevated pregnenolone levels were observed in abiraterone-treated CRPC patients $(16.3 \mathrm{nM}$, IQR 9.85-27.77 nM) using LC-MS/MS, and it was also noted that patients with high serum abiraterone levels (>35 ng/mL) had higher pregnenolone levels than patients with low abiraterone concentrations (McKay et al. 2017). This can be explained by impaired conversion of pregnenolone to $17 \mathrm{OH}$-pregnenolone because of CYP17A1 inhibition by abiraterone, resulting in the accumulation of the former steroid.

Progesterone is not often considered in the context of androgens and prostate cancer, despite its wellcharacterized activation of AR mutants and the assumed protective role of the stromal progesterone receptor in BPH and PC development (Chen et al. 2017). Serum concentrations in healthy male controls are slightly lower than those for pregnenolone, with reported means around $0.5-0.75 \mathrm{nM}$ (Hammond et al. 1978, Belanger et al. 1994).

Hammond and coworkers observed no clear differences in progesterone levels between controls and $\mathrm{BPH}$ or PC subjects, and Ayub and Levell observed no change in progesterone levels in PC patients treated with orchiectomy or ADT (Hammond et al. 1978). However, they did observe higher mean values at baseline $(1.53-1.83 \mathrm{nM}$ ) than Hammond and coworkers (Ayub \& Levell 1990, Hammond et al. 1978). Since progesterone is subject to hydrolysis by CYP17A1, LC-MS/MS-measured serum progesterone levels were mildly increased in abiraterone-treated subjects (median $2.77 \mathrm{nM}$, IQR $1.62-5.18 \mathrm{nM}$ ) (McKay et al. 2017). Both pregnenolone and progesterone serum levels were increased by enzalutamide treatment in eugonadal setting, again suggesting increased hypothalamic-pituitary-gonadal axis activity. However, adjuvant combination treatment with enzalutamide, dutasteride and ADT does not result in an increase in pregnenolone and significantly lowers progesterone (Montgomery et al. 2017).

\section{OH-pregnenolone and $170 \mathrm{H}-$ progesterone}

Derived from pregnenolone, $17 \mathrm{OH}-$ pregnenolone is an intermediate in the production of androgens as it can be converted into DHEA by the 17,20-lyase activity of CYP17A1. Belanger and coworkers reported a mean serum $17 \mathrm{OH}$-pregnenolone of $2.01 \mathrm{nM}$ in healthy controls, and a total range of $1.08-12.3 \mathrm{nM}$ is reported elsewhere (Kushnir et al. 2006, Belanger et al. 1994).

$17 \mathrm{OH}$-pregnenolone levels are rarely reported in human subjects in the context of prostate cancer. Two small studies reported values for PC patients before and after treatment with estrogens, but $17 \mathrm{OH}$-pregnenolone levels appeared to be unaffected (Hammond et al. 1977, Kitahara et al. 1999). Since abiraterone inhibits CYP17A1 activity, it is likely that serum $17 \mathrm{OH}$-pregnenolone levels will be impaired in patients taking this drug.

$17 \mathrm{OH}$-progesterone is the product of hydrolysis of progesterone by CYP17A1 and is a glucocorticoid precursor. Serum concentrations decline with age (Belanger et al. 1994) and reported concentrations are in the $0.75-4.2 \mathrm{nM}$ range for healthy controls (Hammond et al. 1978, Kushnir et al. 2006). 17OH-progesterone levels are similar in BPH and PC subjects and appear to be unaffected by orchiectomy or ADT (Hammond et al. 1978, Ayub \& Levell 1990). Unfortunately, data in abirateronetreated patients are not available.

\section{Androsterone}

Androsterone is an inactive metabolite of DHT, but can also be converted back to DHT through the actions

Published by Bioscientifica Ltd. 
of 17 $\beta$-HSD types 5 (AKR1C3), 6 (HSD17B6) and 10 (HSD17B10). It is also an intermediate of the backdoor DHT synthesis pathway (Arlt et al. 2004, Auchus 2004). Mean serum values for healthy controls were found to be between 1.4 and $2.87 \mathrm{nM}$ (Belanger et al. 1994), although a slightly lower range of 1-1.5 nM was observed elsewhere (Hammond et al. 1978).

This latter study also did not observe a difference between control and $\mathrm{BPH}$ or PC subjects. Two other recent studies using LC-MS/MS (Mostaghel et al. 2014, Taplin et al. 2014) report mean values for PC patients (0.49 and $0.28-0.34 \mathrm{nM}$, respectively) that are below the range reported by Hammond and coworkers (0.5-2.2 nM) (Hammond et al. 1978). This difference is likely due to the use of liquid chromatography/tandem mass spectrometry in the former studies, preventing assay cross-reactivity among steroid hormone measurements. ADT treatment reduced serum androsterone levels by approximately 50\% in both of these studies, reaching levels between 0.16 and $0.28 \mathrm{nM}$ (Mostaghel et al. 2014, Taplin et al. 2014). The abiraterone-treated subjects in the study of Taplin and coworkers reached serum androsterone concentrations below their LC-MS/MS assay detection limit of $0.03 \mathrm{nM}$ (Taplin et al. 2014).

\section{$3 \alpha$-androstanediol}

3 $\alpha$-androstanediol $\quad(5 \alpha$-androstane- $3 \alpha, 17 \beta$-diol $), \quad$ a metabolite of DHT, is usually measured in its inactive glucuronidized metabolite, $3 \alpha$-androstanediolglucuronide. Studies analyzed by the EHPCCG report median values between 5.7 and $14.5 \mathrm{nM}$, with IQRs ranging from 3.9 to $19.8 \mathrm{nM}$ (Endogenous Hormones and Prostate Cancer Collaborative Group 2008). These levels have been confirmed in more recent studies (Wiren et al. 2007, Schenk et al. 2016).

\section{Glucocorticoids and precursors}

This class of steroid hormones is not known for its causative role in prostate cancer, but the glucocorticoid receptor has been implicated in advanced stages of disease (Arora et al. 2013).

Recently, altered metabolism of cortisolby intratumoral $11 \beta$-hydroxysteroid dehydrogenase type 2 loss has been discovered as a resistance mechanism to enzalutamide treatment (Li et al. 2017). Levels of cortisol, the main effector glucocorticoid, adhere to a circadian rhythm with a peak during the morning (138-635 nM) and a steady decline until a nadir is reached during the night (Auchus et al. 2014). Cortisol and its precursor 11-deoxycortisol are conversion products of $17 \mathrm{OH}$-progesterone and are thus dependent on CYP17A1 activity. It is not expected that cortisol levels are aberrant in BPH or PC patients. Indeed, mean morning cortisol concentrations of 536 and $509 \mathrm{nM}$ were observed in patient with local and advanced prostate cancer, respectively (Heracek et al. 2007b).

Inhibition of cortisol production following abiraterone treatment without addition of glucocorticoids causes withdrawal of negative feedback at the hypothalamic and pituitary level and subsequently increases ACTH levels up to 6-fold. Hence, cortisol levels remain relatively constant at baseline, but responses to ACTH following a short synacthen test were invariably insufficient. Since ACTH subsequently drives the production of mineralocorticoids with hypertensive capabilities and possibly also adrenal androgens, abiraterone is co-administered with the glucocorticoid prednisone, which is now the standard care treatment (O'Donnell et al. 2004, Attard et al. 2008). Indeed, mean cortisol levels declined from $303.6-358.8 \mathrm{nM}$ to $124.2-276 \mathrm{nM}$ after 21 days of abiraterone and corticosteroid co-treatment. Interestingly, 11-deoxycortisol levels were increased as a consequence of abiraterone treatment, from $0.867-2.60 \mathrm{nM}$ to 2.89-9.39 nM (Ryan et al. 2010), confirming inhibition of 11ß-hydroxylase in vivo (Yin \& Hu 2014).

Glucocorticoids may also impose more direct effects on prostate cancer proliferation upon mutation of the androgen receptor. Treatment with hormonal therapy in CRPC patients positively selects for mutations in the AR ligand-binding domain, several of which can be activated by glucocorticoids (Carreira et al. 2014, Romanel et al. 2015). This is very relevant to abiraterone-treated patients for two reasons. Firstly, abiraterone is commonly co-administered with the GR agonist prednisone and, secondly, abiraterone-treated patients have elevated corticosterone levels, which also has GR activity (discussed below).

\section{Mineralocorticoids and precursors}

Mineralocorticoids are not known to be effectors of prostate cancer signaling and proliferation. These steroids are involved in fluid and electrolyte homeostasis and thus do not appear to play a major role in the development of prostate cancer. However, abiraterone inhibits synthesis of downstream steroids, causing pregnenolone and progesterone levels to accumulate. Similar to 
glucocorticoids, no fluctuations in mineralocorticoids have been described in BPH or ADT-treated PC patients.

In abiraterone-treated patients, a strong increase was observed in deoxycorticosterone (DOC) from 0.196 to $2.07 \mathrm{nM}$ (median) and in corticosterone from 3.83 to $188.0 \mathrm{nM}$ (median) (Attard et al. 2008). Although cortisol is the main glucocorticoid in humans, corticosterone also has glucocorticoid activity. Several papers have shown that the mineralocorticoid excess can be treated by addition of prednisone ( $5 \mathrm{mg}$ daily) or dexamethasone ( $0.5 \mathrm{mg}$ daily), which is why abiraterone is always co-administered with exogenous glucocorticoids (Attard et al. 2008, Ryan et al. 2010, Pia et al. 2013). Additional inhibition of the mineralocorticoid receptor can be accomplished by eplerenone, whereas spironolactone should be avoided due to its capability of AR activation (Richards et al. 2012). Although strong elevation of DOC and corticosterone was observed in the study by Ryan and coworkers aldosterone levels remained relatively stable (Ryan et al. 2010). This is likely due to effects of ACTH, which primarily stimulates the zona fasciculata rather than the zona glomerulosa, which produces aldosterone and contains aldosterone synthase (CYP11B2). Thus, the mineralocorticoid excess symptoms in abiraterone-treated patients are caused by the mineralocorticoid DOC.

\section{Alternative pathways of androgen synthesis}

In addition to the canonical pathway of DHT synthesis, involving gonadal-derived testosterone, alternative pathways have been proposed recently (Auchus 2004, Chang et al. 2011). It has been shown that androstenedione can be preferentially converted into $5 \alpha$-androstanedione by SRD5A1 (Chang et al. 2011), the isozyme that is upregulated in CRPC tissue (Titus et al. 2005). To our knowledge, there are no studies reporting circulating $5 \alpha$-androstanedione levels in male subjects or patients with prostate cancer.

Alternatively, another mechanism involving $5 \alpha$-reduction of progesterone and synthesis of allopregnanolone may lead to the production DHT without involvement of canonical androgen pathway intermediates (Fukami et al. 2013). In this pathway, allopregnanolone is metabolized with high efficiency into androsterone by CYP17A1 (Auchus 2004). Since abiraterone reduces levels of canonical androgens and leads to accumulation of progesterone metabolites, this pathway may be of particular interest in patients that progress on abiraterone. Indeed urinary steroid metabolite analysis in PC patients treated with abiraterone revealed augmented concentrations of backdoor pathway metabolites (Attard et al. 2012). However, serum values of backdoor pathway intermediates in this group or other PC patients in general are missing.

Finally, there is another class of 11-oxygenated C19 steroids that may play an important role in prostate cancer that has previously been overlooked. After DHEAS, $11 \mathrm{OH}$-androstenedione is the most prevalent androgen precursor produced by the adrenal cortex. It can be produced from androstenedione by CYP11B1, and although this steroid itself does not activate the AR, it can be converted into 11-keto variants of testosterone and DHT that are equally potent agonists of the AR (Swart \& Storbeck 2015, Pretorius et al. 2016). Plasma levels of $11 \mathrm{OH}$-androstenedione and 11keto-testosterone have recently been investigated and shown to reach a high baseline and augmented post-ADT levels of above $100 \mathrm{nM}$ (du Toit et al. 2017). Notably, 11keto-DHT levels were in the $10-20 \mathrm{nM}$ range before treatment and showed no decrease after ADT, suggesting significant AR activation potential. This is also reflected by prominent tissue levels of these 11-oxygenated C19 steroids (du Toit et al. 2017). Until recently, these steroids and their physiological role has been overlooked in the literature and an increasing number of studies now confirm these steroids as interesting targets for androgen-dependent diseases, including PC.

\section{Discussion and future prospects}

Improving our understanding of steroid hormones, their homeostasis and their involvement in prostate cancer pathogenesis has been a central feature of prostate cancer research for decades. Research has focused predominantly on the canonical AR ligands testosterone and DHT. Limited data are available on the adrenal derived androgens DHEA and androstenedione, but little is known about possible variations in upstream steroids. Similarly, data on steroids downstream of testosterone and DHT are scarce.

The recent paradigm shift in treatment of $\mathrm{PC}$ with novel second-line hormonal therapy also necessitates accurate studies into the effects of these drugs on circulating and intratumoral hormone levels. This should also include the effects of enzalutamide. Aberrant hormonal pathways have been identified, but it is clear that we still do not fully understand how resistance occurs in many patients. It is therefore important that more data are obtained from these subjects. Making use of LC-MS/MS technological advancement to detect very small changes and measure 
steroids at increasingly lower limits of quantification will be key to progressing our knowledge.

Inter-study variation is a relevant drawback complicating comparisons between different studies. Within the EHPCCG meta-study alone, median and IQR values vary drastically on a study-to-study basis. A value fitting securely within the normal range of one study may be considered aberrant compared to the normal range of another study. Without access to all the potential confounders within each individual study, it is necessary to consider a broader 'normal' range. Then, however, it becomes important not to lose track of potential small differences between two distinct populations, even if these values both fit within the broader normal range. For example, considering the small difference in estradiol levels between ADT-sensitive and CRPC subjects observed within the study of Qin and coworkers, it is possible that both values fall within a broader range of 'normal' estradiol levels, but a subtle shift may still be informative (Qin et al 2013). Those subtle changes, rather than more drastic shifts, may play an important role in the occurrence of resistance pathways.

The exact relevance of such subtle changes becomes apparent in the context of in vitro AR activation assays (Mizokami et al. 2004, Sonneveld et al. 2005, Dennis et al. 2008, Campana et al. 2016). Serum testosterone and DHT levels in healthy subjects greatly surpass the $\mathrm{EC}_{50}$ values required for AR activation. However, ADT lowers serum testosterone and DHT to levels near or below the $\mathrm{EC}_{50}$ values, and this is accompanied by a PSA decline in most castrate patients. Abiraterone is capable of further lowering testosterone levels below the activation threshold and lowering DHT levels to the $\mathrm{EC}_{50}$ threshold, subsequently accompanied by an additional decline in serum PSA (McKay et al. 2017). Small changes within this range may therefore greatly affect activation of the androgen receptor.

Levels of androstenedione and DHEA do not appear to reach sufficient levels in vivo to significantly contribute to AR activation under castrate conditions. However, these steroids may contribute to an important phenomenon observed in patient biopsies: high intracellular concentrations of DHT and testosterone despite castration serum testosterone levels (Montgomery et al. 2008, Mostaghel 2014, Taplin et al. 2014). These concentrations are sufficient to fully activate the AR and consequently intracellular steroidogenesis constitutes an important factor in cancer progression after castration. Elucidating this process of intracellular steroidogenesis is an important aim for further investigations, but unfortunately, CRPC tissue samples are difficult to obtain.

Abiraterone strongly reduces intraprostatic DHEA, androstenedione and DHT levels (Taplin et al. 2014) and may thus impair intracellular steroid hormone conversion. However, it is important to consider serum DHEAS levels, which are in the $>100 \mathrm{nM}$ range in abiraterone-treated patients (Taplin et al. 2014). DHEAS remains an important potential depot for downstream androgens synthesis (Tamae et al. 2015) after abiraterone treatment, particularly since organic anion transporting polypeptides (OATPs) associated with DHEAS uptake appear to be upregulated after androgen deprivation, at least in vitro (Arakawa et al. 2012).

While the clinical benefits of enzalutamide in different settings are being studied thoroughly, the effects of enzalutamide on steroid metabolism have been rarely reported. Only a single study reported serum steroid levels after enzalutamide treatment in the neoadjuvant setting for patients with high-risk localized prostate cancer who are scheduled to undergo prostatectomy (Montgomery et al. 2017). This study shows that while enzalutamide is a direct AR antagonist, it does significantly affect serum steroid levels, including elevated levels of testosterone and DHT. As far as we know, serum steroid levels after enzalutamide in the CRPC setting have not been reported in literature thus far, which represents an obvious omission in our understanding of resistance in the CRPC patients on enzalutamide therapy.

Finally, the alternative DHT synthesis pathways and the 11-oxygenated C19 steroids are also important considerations for further investigations, especially in CRPC patients. Hopefully, future studies will be able to elucidate the mechanisms of intracellular steroidogenesis and reveal its contribution in the castrate, abiraterone and post-abiraterone setting. Currently, little is known about the effects of the hormonal therapies on the levels of 11-oxygenated C19 steroids.

For a long time CRPC has been considered androgenindependent (Nelson et al. 2003). Recent preclinical developments and the successful introduction of

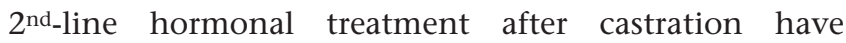
firmly established the relevance of residual presence of intratumoral androgens. Even following abiraterone treatment, steroid hormones can still significantly affect AR activation. Consequently, circulating steroid hormone levels continue to require clinical consideration and offer relevant targets for optimization or improvement of treatment of patients with advanced PC. 


\section{Supplementary data}

This is linked to the online version of the paper at http://dx.doi.org/10.1530/ ERC-17-0155.

\section{Declaration of interest}

The authors declare that there is no conflict of interest that could be perceived as prejudicing the impartiality of this review.

\section{Funding}

This work was supported by the 7th Framework Programme (FP7)-People Marie Curie actions Intra-European Fellowships (grant number 629745) and the Daniel den Hoed foundation.

\section{References}

Ahern T, Swiecicka A, Eendebak RJ, Carter EL, Finn JD, Pye SR, O’Neill TW, Antonio L, Keevil B, Bartfai G, et al. 2016 Natural history, risk factors and clinical features of primary hypogonadism in ageing men: longitudinal data from the European male aging study. Clinical Endocrinology 85 891-901. (doi:10.1111/cen.13152)

Arakawa H, Nakanishi T, Yanagihara C, Nishimoto T, Wakayama T, Mizokami A, Namiki M, Kawai K \& Tamai I 2012 Enhanced expression of organic anion transporting polypeptides (OATPs) in androgen receptor-positive prostate cancer cells: possible role of OATP1A2 in adaptive cell growth under androgen-depleted conditions. Biochemical Pharmacology 84 1070-1077. (doi:10.1016/j. bcp.2012.07.026)

Arlt W, Walker EA, Draper N, Ivison HE, Ride JP, Hammer F, Chalder SM, Borucka-Mankiewicz M, Hauffa BP, Malunowicz EM, et al. 2004 Congenital adrenal hyperplasia caused by mutant $\mathrm{P} 450$ oxidoreductase and human androgen synthesis: analytical study. Lancet 363 2128-2135. (doi:10.1016/S0140-6736(04)16503-3)

Arora VK, Schenkein E, Murali R, Subudhi SK, Wongvipat J, Balbas MD, Shah N, Cai L, Efstathiou E, Logothetis C, et al. 2013 Glucocorticoid receptor confers resistance to antiandrogens by bypassing androgen receptor blockade. Cell 155 1309-1322. (doi:10.1016/j. cell.2013.11.012)

Askew EB, Gampe RT Jr, Stanley TB, Faggart JL \& Wilson EM 2007 Modulation of androgen receptor activation function 2 by testosterone and dihydrotestosterone. Journal of Biological Chemistry 282 25801-25816. (doi:10.1074/jbc.M703268200)

Attard G, Reid AH, Yap TA, Raynaud F, Dowsett M, Settatree S, Barrett M, Parker C, Martins V, Folkerd E, et al. 2008 Phase I clinical trial of a selective inhibitor of CYP17, abiraterone acetate, confirms that castration-resistant prostate cancer commonly remains hormone driven. Journal of Clinical Endocrinology and Metabolism 26 4563-4571. (doi:10.1200/JCO.2007.15.9749)

Attard G, Reid AH, A'Hern R, Parker C, Oommen NB, Folkerd E, Messiou C, Molife LR, Maier G, Thompson E, et al. 2009 Selective inhibition of CYP17 with abiraterone acetate is highly active in the treatment of castration-resistant prostate cancer. Journal of Clinical Oncology 27 3742-3748. (doi:10.1200/JCO.2008.20.0642)

Attard G, Reid AH, Auchus RJ, Hughes BA, Cassidy AM, Thompson E, Oommen NB, Folkerd E, Dowsett M, Arlt W, et al. 2012 Clinical and biochemical consequences of CYP17A1 inhibition with abiraterone given with and without exogenous glucocorticoids in castrate men with advanced prostate cancer. Journal of Clinical Endocrinology and Metabolism 97 507-516. (doi:10.1210/jc.2011-2189)
Attard G, Parker C, Eeles RA, Schroder F, Tomlins SA, Tannock I, Drake CG \& de Bono JS 2016 Prostate cancer. Lancet 387 70-82. (doi:10.1016/S0140-6736(14)61947-4)

Auchus RJ 2004 The backdoor pathway to dihydrotestosterone. Trends in Endocrinology and Metabolism 15 432-438. (doi:10.1016/j. tem.2004.09.004)

Auchus RJ, Yu MK, Nguyen S \& Mundle SD 2014 Use of prednisone with abiraterone acetate in metastatic castration-resistant prostate cancer. Oncologist 19 1231-1240. (doi:10.1634/ theoncologist.2014-0167)

Ayub M \& Levell MJ 1990 Suppression of plasma androgens by the antiandrogen flutamide in prostatic cancer patients treated with Zoladex, a GnRH analogue. Clinical Endocrinology 32 329-339. (doi:10.1111/j.1365-2265.1990.tb00874.x)

Basaria S, Lieb J 2nd, Tang AM, DeWeese T, Carducci M, Eisenberger M \& Dobs AS 2002 Long-term effects of androgen deprivation therapy in prostate cancer patients. Clinical Endocrinology 56 779-786. (doi:10.1046/j.1365-2265.2002.01551.x)

Beer TM, Armstrong AJ, Rathkopf DE, Loriot Y, Sternberg CN, Higano CS, Iversen P, Bhattacharya S, Carles J, Chowdhury S, et al. 2014 Enzalutamide in metastatic prostate cancer before chemotherapy. New England Journal of Medicine 371 424-433. (doi:10.1056/NEJMoa1405095)

Belanger A, Candas B, Dupont A, Cusan L, Diamond P, Gomez JL \& Labrie F 1994 Changes in serum concentrations of conjugated and unconjugated steroids in 40- to 80-year-old men. Journal of Clinical Endocrinology and Metabolism 79 1086-1090.

Bjerregaard-Olesen C, Ghisari M, Kjeldsen LS, Wielsoe M \& BonefeldJorgensen EC 2016 Estrone sulfate and dehydroepiandrosterone sulfate: transactivation of the estrogen and androgen receptor Steroids 105 50-58. (doi:10.1016/j.steroids.2015.11.009)

Bremner WJ, Vitiello MV \& Prinz PN 1983 Loss of circadian rhythmicity in blood testosterone levels with aging in normal men. Journal of Clinical Endocrinology and Metabolism 56 1278-1281. (doi:10.1210/ jcem-56-6-1278)

Campana C, Rege J, Turcu AF, Pezzi V, Gomez-Sanchez CE, Robins DM \& Rainey WE 2016 Development of a novel cell based androgen screening model. Journal of Steroid Biochemistry and Molecular Biology 156 17-22. (doi:10.1016/j.jsbmb.2015.11.005)

Cao S, Zhan Y \& Dong Y 2016 Emerging data on androgen receptor splice variants in prostate cancer. Endocrine-Related Cancer 23 T199-T210. (doi:10.1530/ERC-16-0298)

Carreira S, Romanel A, Goodall J, Grist E, Ferraldeschi R, Miranda S, Prandi D, Lorente D, Frenel JS, Pezaro C, et al. 2014 Tumor clone dynamics in lethal prostate cancer. Science Translational Medicine 6 254ra125.

Chang KH, Li R, Papari-Zareei M, Watumull L, Zhao YD, Auchus RJ \& Sharifi N 2011 Dihydrotestosterone synthesis bypasses testosterone to drive castration-resistant prostate cancer. PNAS 108 13728-13733. (doi:10.1073/pnas.1107898108)

Chen C, Weiss NS, Stanczyk FZ, Lewis SK, DiTommaso D, Etzioni R, Barnett MJ \& Goodman GE 2003 Endogenous sex hormones and prostate cancer risk: a case-control study nested within the carotene and retinol efficacy trial. Cancer Epidemiology, Biomarkers and Prevention 12 1410-1416.

Chen CD, Welsbie DS, Tran C, Baek SH, Chen R, Vessella R, Rosenfeld MG \& Sawyers CL 2004a Molecular determinants of resistance to antiandrogen therapy. Nature Medicine 10 33-39. (doi:10.1038/nm972)

Chen F, Knecht K, Leu C, Rutledge SJ, Scafonas A, Gambone C, Vogel R, Zhang H, Kasparcova V, Bai C, et al. 2004b Partial agonist/antagonist properties of androstenedione and 4-androsten-3beta,17beta-diol. Journal of Steroid Biochemistry and Molecular Biology 91 247-257. (doi:10.1016/j.jsbmb.2004.04.009)
(C) 2017 Society for Endocrinology Printed in Great Britain
Published by Bioscientifica Ltd 
Chen R, Yu Y \& Dong X 2017 Progesterone receptor in the prostate: a potential suppressor for benign prostatic hyperplasia and prostate cancer. Journal of Steroid Biochemistry and Molecular Biology 166 91-96. (doi:10.1016/j.jsbmb.2016.04.008)

Chien Y, Rosal K \& Chung BC 2017 Function of CYP11A1 in the mitochondria. Molecular and Cellular Endocrinology 441 55-61. (doi:10.1016/j.mce.2016.10.030)

Clark RV, Hermann DJ, Cunningham GR, Wilson TH, Morrill BB \& Hobbs S 2004 Marked suppression of dihydrotestosterone in men with benign prostatic hyperplasia by dutasteride, a dual 5alphareductase inhibitor. Journal of Clinical Endocrinology and Metabolism 89 2179-2184. (doi:10.1210/jc.2003-030330)

Conteduca V, Crabb SJ, Scarpi E, Hanna C, Maines F, Joyce H, Fabbri P, Derosa L, Massari F, Lolli C, et al. 2016 Association between early PSA increase and clinical outcome in patients treated with enzalutamide for metastatic castration resistant prostate cancer. Molecular Diagnosis and Therapy 20 255-263. (doi:10.1007/s40291016-0196-1)

Crawford ED, Barqawi AB, O'Donnell C \& Morgentaler A 2007 The association of time of day and serum testosterone concentration in a large screening population. BJU International 100 509-513. (doi:10.1111/j.1464-410X.2007.07022.x)

Daniels NA, Nielson CM, Hoffman AR, Bauer DC \& Osteoporotic Fracture In Men Study G 2010 Sex hormones and the risk of incident prostate cancer. Urology 76 1034-1040. (doi:10.1016/j.urology.2010.01.086)

de Bono JS, Logothetis CJ, Molina A, Fizazi K, North S, Chu L, Chi KN, Jones RJ, Goodman OB Jr, Saad F, et al. 2011 Abiraterone and increased survival in metastatic prostate cancer. New England Journal of Medicine 364 1995-2005. (doi:10.1056/NEJMoa1014618)

Dennis MK, Bowles HJ, MacKenzie DA, Burchiel SW, Edwards BS, Sklar LA, Prossnitz ER \& Thompson TA 2008 A multifunctional androgen receptor screening assay using the high-throughput Hypercyt flow cytometry system. Cytometry Part A 73 390-399. (doi:10.1002/cyto.a.20552)

Diver MJ, Imtiaz KE, Ahmad AM, Vora JP \& Fraser WD 2003 Diurnal rhythms of serum total, free and bioavailable testosterone and of SHBG in middle-aged men compared with those in young men. Clinical Endocrinology 58 710-717. (doi:10.1046/j.13652265.2003.01772.x

du Toit T, Bloem LM, Quanson JL, Ehlers R, Serafin AM \& Swart AC 2017 Profiling adrenal 11beta-hydroxyandrostenedione metabolites in prostate cancer cells, tissue and plasma: UPC2-MS/MS quantification of 11beta-hydroxytestosterone, 11keto-testosterone and 11keto-dihydrotestosterone. Journal of Steroid Biochemistry and Molecular Biology 166 54-67. (doi:10.1016/j.jsbmb.2016.06.009)

Duff J \& McEwan IJ 2005 Mutation of histidine 874 in the androgen receptor ligand-binding domain leads to promiscuous ligand activation and altered p160 coactivator interactions. Molecular Endocrinology 19 2943-2954. (doi:10.1210/me.2005-0231)

Endogenous Hormones and Prostate Cancer Collaborative Group, Roddam AW, Allen NE, Appleby P \& Key TJ 2008 Endogenous sex hormones and prostate cancer: a collaborative analysis of 18 prospective studies. Journal of the National Cancer Institute $\mathbf{1 0 0}$ 170-183. (doi:10.1093/jnci/djm323)

Forman F \& Ferlay J 2014 The global and regional burden of cancer. In World Cancer Report 2014, pp16-54. Eds BW Stewart \& CP Wild. Lyon, France; International Agency for Research on Cancer.

Fukami M, Homma K, Hasegawa T \& Ogata T 2013 Backdoor pathway for dihydrotestosterone biosynthesis: implications for normal and abnormal human sex development. Developmental Dynamics 242 320-329. (doi:10.1002/dvdy.23892)

Gann PH, Hennekens CH, Ma J, Longcope C \& Stampfer MJ 1996 Prospective study of sex hormone levels and risk of prostate cancer. Journal of the National Cancer Institute 88 1118-1126. (doi:10.1093/ jnci/88.16.1118)
Gao W, Bohl CE \& Dalton JT 2005 Chemistry and structural biology of androgen receptor. Chemical Reviews 105 3352-3370. (doi:10.1021/ cr020456u)

Giagulli VA, Kaufman JM \& Vermeulen A 1994 Pathogenesis of the decreased androgen levels in obese men. Journal of Clinical Endocrinology and Metabolism 79 997-1000.

Grosman H, Fabre B, Mesch V, Lopez MA, Schreier L, Mazza O \& Berg G 2010 Lipoproteins, sex hormones and inflammatory markers in association with prostate cancer. Aging Male 13 87-92. (doi:10.3109/13685530903410617)

Hamdy FC, Donovan JL, Lane JA, Mason M, Metcalfe C, Holding P, Davis M, Peters TJ, Turner EL, Martin RM, et al. 2016 10-year outcomes after monitoring, surgery, or radiotherapy for localized prostate cancer. New England Journal of Medicine 375 1415-1424. (doi:10.1056/NEJMoa1606220)

Hammer F, Subtil S, Lux P, Maser-Gluth C, Stewart PM, Allolio B \& Arlt W 2005 No evidence for hepatic conversion of dehydroepiandrosterone (DHEA) sulfate to DHEA: in vivo and in vitro studies. Journal of Clinical Endocrinology and Metabolism 90 3600-3605. (doi:10.1210/jc.2004-2386)

Hammond GL, Ruokonen A, Kontturi M, Koskela E \& Vihko R 1977 The simultaneous radioimmunoassay of seven steroids in human spermatic and peripheral venous blood. Journal of Clinical Endocrinology and Metabolism 45 16-24. (doi:10.1210/jcem-45-1-16)

Hammond GL, Kontturi M, Vihko P \& Vihko R 1978 Serum steroids in normal males and patients with prostatic diseases. Clinical Endocrinology 9 113-121. (doi:10.1111/j.1365-2265.1978.tb02189.x)

Hara N, Takizawa I, Isahaya E, Nishiyama T, Hoshii T, Ishizaki F \& Takahashi K 2012 Insulin-like growth factor-1 is associated with regulation of the luteinizing hormone production in men receiving androgen deprivation therapy with gonadotropin-releasing hormone analogues for localized prostate cancer. Urologic Oncology $\mathbf{3 0}$ 596-601. (doi:10.1016/j.urolonc.2010.11.001)

Hara N, Ishizaki F, Saito T, Nishiyama T, Kawasaki T \& Takahashi K 2013 Decrease in lean body mass in men with prostate cancer receiving androgen deprivation therapy: mechanism and biomarkers. Urology 81 376-380. (doi:10.1016/j.urology.2012.10.050)

Harman SM, Metter EJ, Tobin JD, Pearson J, Blackman MR \& Baltimore Longitudinal Study of Aging 2001 Longitudinal effects of aging on serum total and free testosterone levels in healthy men. Baltimore longitudinal study of aging. Journal of Clinical Endocrinology and Metabolism 86 724-731. (doi:10.1210/jcem.86.2.7219)

Harris WP, Mostaghel EA, Nelson PS \& Montgomery B 2009 Androgen deprivation therapy: progress in understanding mechanisms of resistance and optimizing androgen depletion. Nature Clinical Practice Urology 6 76-85. (doi:10.1038/ncpuro1296)

Heracek J, Hampl R, Hill M, Starka L, Sachova J, Kuncova J, Eis V, Urban M \& Mandys V 2007a Tissue and serum levels of principal androgens in benign prostatic hyperplasia and prostate cancer. Steroids 72 375-380. (doi:10.1016/j.steroids.2007.01.004)

Heracek J, Urban M, Sachova J, Kuncova J, Eis V, Mandys V, Hampl R \& Starka L $2007 b$ The endocrine profiles in men with localized and locally advanced prostate cancer treated with radical prostatectomy. Neuroendocrinology Letters 28 45-51.

Hofland J, van Weerden WM, Dits NF, Steenbergen J, van Leenders GJ, Jenster G, Schroder FH \& de Jong FH 2010 Evidence of limited contributions for intratumoral steroidogenesis in prostate cancer. Cancer Research 70 1256-1264. (doi:10.1158/0008-5472.CAN-09-2092)

Hsing AW \& Comstock GW 1993 Serological precursors of cancer: serum hormones and risk of subsequent prostate cancer. Cancer Epidemiology, Biomarkers and Prevention 2 27-32.

Ishizaki F, Hara N, Takizawa I, Nishiyama T, Isahaya E, Kawasaki T \& Takahashi K 2012 Deficiency in androgens and upregulation of insulin-like growth factor-1 are involved in high bone turnover in men receiving androgen deprivation therapy for prostate cancer.
C 2017 Society for Endocrinology Printed in Great Britain
Published by Bioscientifica Ltd. 
Growth Hormone and IGF Research 22 122-128. (doi:10.1016/j. ghir.2012.04.003)

Ishizaki F, Nishiyama T, Kawasaki T, Miyashiro Y, Hara N, Takizawa I, Naito M \& Takahashi K 2013 Androgen deprivation promotes intratumoral synthesis of dihydrotestosterone from androgen metabolites in prostate cancer. Scientific Reports 3 1528. (doi:10.1038/srep01528)

Kim W, Zhang L, Wilton JH, Fetterly G, Mohler JL, Weinberg V, Morse A, Szmulewitz RZ, Friedlander TW, Fong L, et al. 2014 Sequential use of the androgen synthesis inhibitors ketoconazole and abiraterone acetate in castration-resistant prostate cancer and the predictive value of circulating androgens. Clinical Cancer Research 20 6269-6276. (doi:10.1158/1078-0432.CCR-14-1595)

Kitahara S, Umeda H, Yano M, Koga F, Sumi S, Moriguchi H, Hosoya Y, Honda M \& Yoshida K 1999 Effects of intravenous administration of high dose-diethylstilbestrol diphosphate on serum hormonal levels in patients with hormone-refractory prostate cancer. Endocrine Journal 46 659-664. (doi:10.1507/endocrj.46.659)

Klotz L \& Emberton M 2014 Management of low risk prostate cancer: active surveillance and focal therapy. Current Opinion in Urology $\mathbf{2 4}$ 270-279. (doi:10.1097/MOU.0000000000000055)

Kok RC, Timmerman MA, Wolffenbuttel KP, Drop SL \& de Jong FH 2010 Isolated 17,20-lyase deficiency due to the cytochrome b5 mutation W27X. Journal of Clinical Endocrinology and Metabolism 95 994-999. (doi:10.1210/jc.2008-1745)

Korpal M, Korn JM, Gao X, Rakiec DP, Ruddy DA, Doshi S, Yuan J, Kovats SG, Kim S, Cooke VG, et al. 2013 An F876L mutation in androgen receptor confers genetic and phenotypic resistance to MDV3100 (enzalutamide). Cancer Discovery 3 1030-1043. (doi:10.1158/2159-8290.CD-13-0142)

Krasowski MD, Drees D, Morris CS, Maakestad J, Blau JL \& Ekins S 2014 Cross-reactivity of steroid hormone immunoassays: clinical significance and two-dimensional molecular similarity prediction. BMC Clinical Pathology 14 33. (doi:10.1186/1472-6890-14-33)

Kumagai J, Hofland J, Erkens-Schulze S, Dits NF, Steenbergen J, Jenster G, Homma Y, de Jong FH \& van Weerden WM 2013 Intratumoral conversion of adrenal androgen precursors drives androgen receptor-activated cell growth in prostate cancer more potently than de novo steroidogenesis. Prostate 73 1636-1650.

Kushnir MM, Rockwood AL, Roberts WL, Pattison EG, Owen WE, Bunker AM \& Meikle AW 2006 Development and performance evaluation of a tandem mass spectrometry assay for 4 adrenal steroids. Clinical Chemistry 52 1559-1567. (doi:10.1373/ clinchem.2006.068445)

Lallous N, Volik SV, Awrey S, Leblanc E, Tse R, Murillo J, Singh K, Azad AA, Wyatt AW, LeBihan S, et al. 2016 Functional analysis of androgen receptor mutations that confer anti-androgen resistance identified in circulating cell-free DNA from prostate cancer patients. Genome Biology 17 10. (doi:10.1186/s13059-015-0864-1)

Li R, Evaul K, Sharma KK, Chang KH, Yoshimoto J, Liu J, Auchus RJ \& Sharifi N 2012 Abiraterone inhibits 3beta-hydroxysteroid dehydrogenase: a rationale for increasing drug exposure in castration-resistant prostate cancer. Clinical Cancer Research 18 3571-3579. (doi:10.1158/1078-0432.CCR-12-0908)

Li Z, Bishop AC, Alyamani M, Garcia JA, Dreicer R, Bunch D, Liu J, Upadhyay SK, Auchus RJ \& Sharifi N 2015 Conversion of abiraterone to D4A drives anti-tumour activity in prostate cancer. Nature $\mathbf{5 2 3}$ 347-351. (doi:10.1038/nature14406)

Li J, Alyamani M, Zhang A, Chang KH, Berk M, Li Z, Zhu Z, Petro M, Magi-Galluzzi C, Taplin ME, et al. 2017 Aberrant corticosteroid metabolism in tumor cells enables GR takeover in enzalutamide resistant prostate cancer. eLife 6 e20183. (doi:10.7554/eLife.20183)

Lin HK, Jez JM, Schlegel BP, Peehl DM, Pachter JA \& Penning TM 1997 Expression and characterization of recombinant type 23 alphahydroxysteroid dehydrogenase (HSD) from human prostate: demonstration of bifunctional 3 alpha/17 beta-HSD activity and cellular distribution. Molecular Endocrinology 11 1971-1984.
Liu C, Lou W, Zhu Y, Yang JC, Nadiminty N, Gaikwad NW, Evans CP \& Gao AC 2015 Intracrine androgens and AKR1C3 activation confer resistance to enzalutamide in prostate cancer. Cancer Research $\mathbf{7 5}$ 1413-1422. (doi:10.1158/0008-5472.CAN-14-3080)

Liu C, Armstrong CM, Lou W, Lombard A, Evans CP \& Gao AC 2017 Inhibition of AKR1C3 activation overcomes resistance to abiraterone in advanced prostate cancer. Molecular Cancer Therapeutics 16 35-44. (doi:10.1158/1535-7163.MCT-16-0186)

Locke JA, Guns ES, Lubik AA, Adomat HH, Hendy SC, Wood CA, Ettinger SL, Gleave ME \& Nelson CC 2008 Androgen levels increase by intratumoral de novo steroidogenesis during progression of castration-resistant prostate cancer. Cancer Research 68 6407-6415. (doi:10.1158/0008-5472.CAN-07-5997)

Matsubara N, Uemura H, Fukui I, Niwakawa M, Yamaguchi A, Iizuka K \& Akaza H 2014 Phase-1 study of abiraterone acetate in chemotherapynaive Japanese patients with castration-resistant prostate cancer. Cancer Science 105 1313-1320. (doi:10.1111/cas.12496)

McKay RR, Werner L, Mostaghel EA, Lis R, Voznesensky O, Zhang Z, Marck BT, Matsumoto AM, Domachevsky L, Zukotynski KA, et al. 2017 A phase II trial of abiraterone combined with dutasteride for men with metastatic castration-resistant prostate cancer. Clinical Cancer Research 23 935-945. (doi:10.1158/1078-0432.CCR-16-0987)

Miller WL \& Auchus RJ 2011 The molecular biology, biochemistry, and physiology of human steroidogenesis and its disorders. Endocrine Reviews 32 81-151. (doi:10.1210/er.2010-0013)

Mitamura K, Nagaoka Y, Shimada K, Honma S, Namiki M, Koh E \& Mizokami A 2003 Simultaneous determination of androstenediol 3-sulfate and dehydroepiandrosterone sulfate in human serum using isotope diluted liquid chromatography-electrospray ionization-mass spectrometry. Journal of Chromatography B: Analytical Technologies in the Biomedical and Life Sciences 796 121-130. (doi:10.1016/j. jchromb.2003.08.011)

Miyoshi Y, Uemura H, Umemoto S, Sakamaki K, Morita S, Suzuki K, Shibata Y, Masumori N, Ichikawa T, Mizokami A, et al. 2014 High testosterone levels in prostate tissue obtained by needle biopsy correlate with poor-prognosis factors in prostate cancer patients. BMC Cancer 14 717. (doi:10.1186/1471-2407-14-717)

Mizokami A, Koh E, Fujita H, Maeda Y, Egawa M, Koshida K, Honma S, Keller ET \& Namiki M 2004 The adrenal androgen androstenediol is present in prostate cancer tissue after androgen deprivation therapy and activates mutated androgen receptor. Cancer Research $\mathbf{6 4}$ 765-771. (doi:10.1158/0008-5472.CAN-03-0130)

Mohler JL, Gregory CW, Ford OH 3rd, Kim D, Weaver CM, Petrusz P, Wilson EM \& French FS 2004 The androgen axis in recurrent prostate cancer. Clinical Cancer Research 10 440-448. (doi:10.1158/1078-0432.CCR-1146-03)

Mondul AM, Selvin E, Rohrmann S, Menke A, Feinleib M, Kanarek N, Rifai N, Dobs AS \& Platz EA 2010 Association of serum cholesterol and cholesterol-lowering drug use with serum sex steroid hormones in men in NHANES III. Cancer Causes Control 21 1575-1583. (doi:10.1007/s10552-010-9586-6)

Montgomery RB, Mostaghel EA, Vessella R, Hess DL, Kalhorn TF, Higano CS, True LD \& Nelson PS 2008 Maintenance of intratumoral androgens in metastatic prostate cancer: a mechanism for castrationresistant tumor growth. Cancer Research 68 4447-4454. (doi:10.1158/0008-5472.CAN-08-0249)

Montgomery B, Tretiakova MS, Joshua AM, Gleave ME, Fleshner N, Bubley GJ, Mostaghel EA, Chi KN, Lin DW, Sanda M, et al. 2017 Neoadjuvant enzalutamide prior to prostatectomy. Clinical Cancer Research 23 2169-2176. (doi:10.1158/1078-0432.CCR-16-1357)

Mostaghel EA 2014 Beyond T and DHT - novel steroid derivatives capable of wild type androgen receptor activation. International Journal of Biological Sciences 10 602-613. (doi:10.7150/ijbs.8844)

Mostaghel EA, Nelson PS, Lange P, Lin DW, Taplin ME, Balk S, Ellis W, Kantoff P, Marck B, Tamae D, et al. 2014 Targeted androgen pathway suppression in localized prostate cancer: a pilot study. Journal of 
Clinical Endocrinology and Metabolism 32 229-237. (doi:10.1200/ JCO.2012.48.6431)

Muller RL, Gerber L, Moreira DM, Andriole G, Castro-Santamaria R \& Freedland SJ 2012 Serum testosterone and dihydrotestosterone and prostate cancer risk in the placebo arm of the reduction by dutasteride of prostate cancer events trial. European Urology 62 757-764. (doi:10.1016/j.eururo.2012.05.025)

Nelson WG, De Marzo AM \& Isaacs WB 2003 Prostate cancer. New England Journal of Medicine 349 366-381. (doi:10.1056/ NEJMra021562)

Nishiyama T, Ikarashi T, Hashimoto Y, Wako K \& Takahashi K 2007 The change in the dihydrotestosterone level in the prostate before and after androgen deprivation therapy in connection with prostate cancer aggressiveness using the Gleason score. Journal of Urology $\mathbf{1 7 8}$ 1282-1288. (doi:10.1016/j.juro.2007.05.138)

Noordam C, Dhir V, McNelis JC, Schlereth F, Hanley NA, Krone N, Smeitink JA, Smeets R, Sweep FC, Claahsen-van der Grinten HL, et al. 2009 Inactivating PAPSS2 mutations in a patient with premature pubarche. New England Journal of Medicine 360 2310-2318. (doi:10.1056/NEJMoa0810489)

O'Donnell A, Judson I, Dowsett M, Raynaud F, Dearnaley D, Mason M, Harland S, Robbins A, Halbert G, Nutley B, et al. 2004 Hormonal impact of the 17alpha-hydroxylase/C $(17,20)$-lyase inhibitor abiraterone acetate (CB7630) in patients with prostate cancer. British Journal of Cancer 90 2317-2325.

Oostdijk W, Idkowiak J, Mueller JW, House PJ, Taylor AE, O'Reilly MW, Hughes BA, de Vries MC, Kant SG, Santen GW, et al. 2015 PAPSS2 deficiency causes androgen excess via impaired DHEA sulfation - in vitro and in vivo studies in a family harboring two novel PAPSS2 mutations. Journal of Clinical Endocrinology and Metabolism 100 E672-E680. (doi:10.1210/jc.2014-3556)

Parsons JK, Palazzi-Churas K, Bergstrom J \& Barrett-Connor E 2010 Prospective study of serum dihydrotestosterone and subsequent risk of benign prostatic hyperplasia in community dwelling men: the Rancho Bernardo study. Journal of Urology 184 1040-1044. (doi:10.1016/j.juro.2010.05.033)

Payne AH 1990 Hormonal regulation of cytochrome P450 enzymes, cholesterol side-chain cleavage and 17 alpha-hydroxylase/C17-20 lyase in Leydig cells. Biology of Reproduction 42 399-404. (doi:10.1095/biolreprod42.3.399)

Penning TM 2014 Androgen biosynthesis in castration-resistant prostate cancer. Endocrine-Related Cancer 21 T67-T78. (doi:10.1530/ERC-14-0109)

Perlmutter MA \& Lepor H 2007 Androgen deprivation therapy in the treatment of advanced prostate cancer. Reviews in Urology 9 (Supplement 1) S3-S8.

Pia A, Vignani F, Attard G, Tucci M, Bironzo P, Scagliotti G, Arlt W, Terzolo M \& Berruti A 2013 Strategies for managing ACTH dependent mineralocorticoid excess induced by abiraterone. Cancer Treatment Reviews 39 966-973. (doi:10.1016/j.ctrv.2013.03.003)

Pretorius E, Africander DJ, Vlok M, Perkins MS, Quanson J \& Storbeck KH 2016 11-ketotestosterone and 11-ketodihydrotestosterone in castration resistant prostate cancer: potent androgens which can no longer be ignored. PLOS ONE 11 e0159867. (doi:10.1371/journal. pone.0159867)

Purohit A \& Foster PA 2012 Steroid sulfatase inhibitors for estrogen- and androgen-dependent cancers. Journal of Endocrinology 212 99-110. (doi:10.1530/JOE-11-0266)

Qin X, Zhang H, Ye D, Yao X, Zhang S \& Dai B 2013 Variations in circulating sex steroid levels in metastatic prostate cancer patients with combined androgen blockade: observation and implication. Andrology 1 512-516. (doi:10.1111/j.2047-2927.2013.00078.x)

Rahman HP, Hofland J \& Foster PA 2016 In touch with your feminine side: how oestrogen metabolism impacts prostate cancer. EndocrineRelated Cancer 23 R249-R266. (doi:10.1530/ERC-16-0118)

Richards J, Lim AC, Hay CW, Taylor AE, Wingate A, Nowakowska K, Pezaro C, Carreira S, Goodall J, Arlt W, et al. 2012 Interactions of abiraterone, eplerenone, and prednisolone with wild-type and mutant androgen receptor: a rationale for increasing abiraterone exposure or combining with MDV3100. Cancer Research 72 2176-2182. (doi:10.1158/0008-5472.CAN-11-3980)

Rohl HF \& Beuke HP 1992 Effect of orchidectomy on serum concentrations of testosterone and dihydrotestosterone in patients with prostatic cancer. Scandinavian Journal of Urology 26 11-14. (doi:10.3109/00365599209180389)

Romanel A, Gasi Tandefelt D, Conteduca V, Jayaram A, Casiraghi N, Wetterskog D, Salvi S, Amadori D, Zafeiriou Z, Rescigno P, et al. 2015 Plasma AR and abiraterone-resistant prostate cancer. Science Translational Medicine 7 312re310.

Ryan KJ \& Engel LL 1957 Hydroxylation of steroids at carbon 21. Journal of Biological Chemistry 225 103-114.

Ryan CJ, Smith MR, Fong L, Rosenberg JE, Kantoff P, Raynaud F, Martins V, Lee G, Kheoh T, Kim J, et al. 2010 Phase I clinical trial of the CYP17 inhibitor abiraterone acetate demonstrating clinical activity in patients with castration-resistant prostate cancer who received prior ketoconazole therapy. Journal of Clinical Endocrinology and Metabolism 28 1481-1488. (doi:10.1200/JCO.2009.24.1281)

Ryan CJ, Molina A, Li J, Kheoh T, Small EJ, Haqq CM, Grant RP, de Bono JS \& Scher HI 2013a Serum androgens as prognostic biomarkers in castration-resistant prostate cancer: results from an analysis of a randomized phase III trial. Journal of Clinical Endocrinology and Metabolism 31 2791-2798. (doi:10.1200/ JCO.2012.45.4595)

Ryan CJ, Smith MR, de Bono JS, Molina A, Logothetis CJ, de Souza P, Fizazi K, Mainwaring P, Piulats JM, Ng S, et al. 2013b Abiraterone in metastatic prostate cancer without previous chemotherapy. New England Journal of Medicine 368 138-148. (doi:10.1056/NEJMoa1209096)

Ryan CJ, Peng W, Kheoh T, Welkowsky E, Haqq CM, Chandler DW, Scher HI \& Molina A 2014 Androgen dynamics and serum PSA in patients treated with abiraterone acetate. Prostate Cancer and Prostatic Diseases 17 192-198. (doi:10.1038/pcan.2014.8)

Saboor Aftab SA, Kumar S \& Barber TM 2013 The role of obesity and type 2 diabetes mellitus in the development of male obesityassociated secondary hypogonadism. Clinical Endocrinology $\mathbf{7 8}$ 330-337. (doi:10.1111/cen.12092)

Schenk JM, Till C, Hsing AW, Stanczyk FZ, Gong Z, Neuhouser ML, Reichardt JK, Hoque AM, Figg WD, Goodman PJ, et al. 2016 Serum androgens and prostate cancer risk: results from the placebo arm of the prostate cancer prevention trial. Cancer Causes Control 27 175-182. (doi:10.1007/s10552-015-0695-0)

Scher HI, Fizazi K, Saad F, Taplin ME, Sternberg CN, Miller K, de Wit R, Mulders P, Chi KN, Shore ND, et al. 2012 Increased survival with enzalutamide in prostate cancer after chemotherapy. New England Journal of Medicine 367 1187-1197. (doi:10.1056/NEJMoa1207506)

Severi G, Morris HA, MacInnis RJ, English DR, Tilley W, Hopper JL, Boyle P \& Giles GG 2006 Circulating steroid hormones and the risk of prostate cancer. Cancer Epidemiology, Biomarkers and Prevention 15 86-91. (doi:10.1158/1055-9965.EPI-05-0633)

Sewer MB \& Waterman MR 2003 ACTH modulation of transcription factors responsible for steroid hydroxylase gene expression in the adrenal cortex. Microscopy Research and Technique 61 300-307. (doi:10.1002/jemt.10339)

Shaw GL, Whitaker H, Corcoran M, Dunning MJ, Luxton H, Kay J, Massie CE, Miller JL, Lamb AD, Ross-Adams H, et al. 2016 The early effects of rapid androgen deprivation on human prostate cancer. European Urology 70 214-218. (doi:10.1016/j.eururo.2015.10.042)

Sonneveld E, Jansen HJ, Riteco JA, Brouwer A \& van der Burg B 2005 Development of androgen- and estrogen-responsive bioassays, members of a panel of human cell line-based highly selective steroid-responsive bioassays. Toxicological Sciences 83 136-148. (doi:10.1093/toxsci/kfi005)

Stanbrough M, Bubley GJ, Ross K, Golub TR, Rubin MA, Penning TM, Febbo PG \& Balk SP 2006 Increased expression of genes converting

Published by Bioscientifica Ltd. 
adrenal androgens to testosterone in androgen-independent prostate cancer. Cancer Research 66 2815-2825. (doi:10.1158/0008-5472.CAN05-4000)

Stanczyk FZ, Azen CG \& Pike MC 2013 Effect of finasteride on serum levels of androstenedione, testosterone and their 5alpha-reduced metabolites in men at risk for prostate cancer. Journal of Steroid Biochemistry and Molecular Biology 138 10-16. (doi:10.1016/j. jsbmb.2013.02.015)

Swart AC \& Storbeck KH 2015 11beta-Hydroxyandrostenedione: downstream metabolism by 11betaHSD, 17betaHSD and SRD5A produces novel substrates in familiar pathways. Molecular and Cellular Endocrinology 408 114-123. (doi:10.1016/j. mce.2014.12.009)

Tamae D, Mostaghel E, Montgomery B, Nelson PS, Balk SP, Kantoff PW, Taplin ME \& Penning TM 2015 The DHEA-sulfate depot following P450c17 inhibition supports the case for AKR1C3 inhibition in high risk localized and advanced castration resistant prostate cancer. Chemico-Biological Interactions 234 332-338. (doi:10.1016/j. cbi.2014.12.012)

Tannock IF, de Wit R, Berry WR, Horti J, Pluzanska A, Chi KN, Oudard S, Theodore C, James ND, Turesson I, et al. 2004 Docetaxel plus prednisone or mitoxantrone plus prednisone for advanced prostate cancer. New England Journal of Medicine 351 1502-1512. (doi:10.1056/NEJMoa040720)

Taplin ME, Montgomery B, Logothetis CJ, Bubley GJ, Richie JP, Dalkin BL, Sanda MG, Davis JW, Loda M, True LD, et al. 2014 Intense androgendeprivation therapy with abiraterone acetate plus leuprolide acetate in patients with localized high-risk prostate cancer: results of a randomized phase II neoadjuvant study. Journal of Clinical Endocrinology and Metabolism 32 3705-3715. (doi:10.1200/JCO.2013.53.4578)

Titus MA, Gregory CW, Ford OH 3rd, Schell MJ, Maygarden SJ \& Mohler JL 2005 Steroid 5alpha-reductase isozymes I and II in recurrent prostate cancer. Clinical Cancer Research 11 4365-4371. (doi:10.1158/1078-0432.CCR-04-0738)

Tran C, Ouk S, Clegg NJ, Chen Y, Watson PA, Arora V, Wongvipat J, Smith-Jones PM, Yoo D, Kwon A, et al. 2009 Development of a second-generation antiandrogen for treatment of advanced prostate cancer. Science 324 787-790. (doi:10.1126/science.1168175)

Trepel J, Mollapour M, Giaccone G \& Neckers L 2010 Targeting the dynamic HSP90 complex in cancer. Nature Reviews Cancer 10 537-549. (doi:10.1038/nrc2887)
Trifiro MD, Parsons JK, Palazzi-Churas K, Bergstrom J, Lakin C \& BarrettConnor E 2010 Serum sex hormones and the 20-year risk of lower urinary tract symptoms in community-dwelling older men. BJU International 105 1554-1559. (doi:10.1111/j.1464-410X.2009.09090.x)

Tsilidis KK, Allen NE, Appleby PN, Rohrmann S, Nothlings U, Arriola L, Gunter MJ, Chajes V, Rinaldi S, Romieu I, et al. 2015 Diabetes mellitus and risk of prostate cancer in the European prospective investigation into cancer and nutrition. International Journal of Cancer 136 372-381. (doi:10.1002/ijc.28989)

van der Sluis TM, Bui HN, Meuleman EJ, Heijboer AC, Hartman JF, van Adrichem N, Boeve E, de Ronde W, van Moorselaar RJ \& Vis AN 2012 Lower testosterone levels with luteinizing hormone-releasing hormone agonist therapy than with surgical castration: new insights attained by mass spectrometry. Journal of Urology 187 1601-1606. (doi:10.1016/j.juro.2011.12.063)

Wiren S, Stocks T, Rinaldi S, Hallmans G, Bergh A, Stenman UH, Kaaks R \& Stattin P 2007 Androgens and prostate cancer risk: a prospective study. Prostate 67 1230-1237.

Wu FC, Tajar A, Pye SR, Silman AJ, Finn JD, O’Neill TW, Bartfai G, Casanueva F, Forti G, Giwercman A, et al. 2008 Hypothalamicpituitary-testicular axis disruptions in older men are differentially linked to age and modifiable risk factors: the European male aging study. Journal of Clinical Endocrinology and Metabolism 93 2737-2745. (doi:10.1210/jc.2007-1972)

Yamashita K, Miyashiro Y, Maekubo H, Okuyama M, Honma S, Takahashi M \& Numazawa M 2009 Development of highly sensitive quantification method for testosterone and dihydrotestosterone in human serum and prostate tissue by liquid chromatographyelectrospray ionization tandem mass spectrometry. Steroids $\mathbf{7 4}$ 920-926. (doi:10.1016/j.steroids.2009.06.007)

Yarrow JF, Beck DT, Conover CF, Beggs LA, Goldberger BA \& Borst SE 2013 Invalidation of a commercially available human 5alphadihydrotestosterone immunoassay. Steroids 78 1220-1225. (doi:10.1016/j.steroids.2013.08.013)

Ye L, Kynaston HG \& Jiang WG 2007 Bone metastasis in prostate cancer: molecular and cellular mechanisms. International Journal of Molecular Medicine 20 103-111.

Yin L \& Hu Q 2014 CYP17 inhibitors - abiraterone, C17,20-lyase inhibitors and multi-targeting agents. Nature Reviews Urology 11 32-42. (doi:10.1038/nrurol.2013.274)

Received in final form 6 September 2017

Accepted 18 September 2017

Accepted preprint published online 18 September 2017
() 2017 Society for Endocrinology Printed in Great Britain
Published by Bioscientifica Ltd 